\title{
La construcción de las identidades racializadas en el cine musical hollywoodense
}

\section{El caso de Billie Holiday en Symphony in black (F. Waller, 1935) y New Orleans (A. Lubin, 1947)}

\author{
María Aparisi Galán
}

Recibido: 26.09.2019 - Aceptado: 15.10.2019

\section{Titre / Title / Titolo}

La construction d'identités racialisées dans

le cinéma musical hollywoodien

The construction of racialized identities in Hollywood musical cinema

La costruzione delle identità razziali nel cinema musicale hollywoodiano

\section{Resumen / Résumé / Abstract / Riassunto}

Este artículo pretende realizar una aproximación crítica a la representación cinematográfica de la afamada cantante de jazz Billie Holiday en el cortometraje musical Symphony in Black (Fred Waller, 1935) y en la película New Orleans (Arthur Lubin, 1947). Concretamente, nos centraremos en el análisis de los estereotipos raciales y de género asignados a la imagen fílmica y a las interpretaciones musicales de la artista, los cuales proporcionarán las claves necesarias para desvelar las dinámicas de rechazo y deseo que existen detrás de la construcción de la «negritud» en el cine de la primera mitad del siglo XX.

Cet article vise à aborder de façon critique la représentation cinématographique de la célèbre chanteuse de jazz Billie Holiday dans le court métrage Symphony in Black (Fred Waller, 1935) et dans le film New Orleans (Arthur Lubin, 1947). Plus précisément, nous nous concentrerons sur l'analyse des stéréotypes raciaux et sexistes assignés à l'image filmique et aux interprétations musicales de l'artiste, qui fourniront les clés nécessaires pour révéler la dynamique de rejet et de désir qui existe derrière la construction de la «négritude» développée par le cinéma musical hollywoodien dans les années 1930 et 1940.
This paper aims to critically approach the cinematographic representation of famed jazz singer Billie Holiday in the short film Symphony in Black (Fred Waller, 1935) and in the film New Orleans (Arthur Lubin, 1947). Specifically, we will focus on the analysis of the racial and gender stereotypes assigned to the filmic image and musical interpretations of the artist, which will provide the keys to undertstanding the dynamics of rejection and desire that exist behind the construction of "blackness" developed by the Hollywood musical cinema of the 1930s and 1940s.

Questo articolo intende affrontare criticamente la rappresentazione cinematografica della famosa cantante jazz Billie Holiday nel cortometraggio Symphony in Black (Fred Waller, 1935) e nel film New Orleans (Arthur Lubin, 1947). In particolare, ci si concentrerà sull'analisi degli stereotipi razziali e di genere assegnati all'immagine filmica e alle interpretazioni musicali dell'artista, che forniranno le chiavi di lettura necessarie per rivelare le dinamiche di rifiuto e desiderio che stanno dietro la costruzione della "negritudine" sviluppata dal cinema musicale hollywoodiano degli anni Trenta e Quaranta.

\section{Palabras clave I Mots-clé I Key words / Parole chiave}

Billie Holiday, racismo, estereotipo, negritud, cine musical. Billie Holiday, racisme, stéréotype, négritude, cinéma musical. Billie Holiday, racism, stereotype, negritude, musical cinema. Billie Holiday, razzismo, stereotipo, negritudine, cinema musicale. 


\section{Introducción: 'Lady Sings the Blues'}

Aquella golfa robusta y grasienta no hacía nada hasta un cuarto de hora antes de que llegara su hombre para la cena. Entonces montaba un verdadero follón. Yo no sabía arreglármelas en su lujosa casa, y en lugar de decirme lo que quería que hiciera, armaba revuelo porque su marido tendría que esperar, me chillaba y me llamaba «negra» con tono despectivo: fue la primera vez que oía esa palabra como si fuera un insulto (Holiday, 2015: 30-31).

A la hora de abordar el estudio sobre la imagen de la afamada vocalista de jazz Billie Holiday no deja indiferente la gran cantidad de biografías que se han publicado de la misma. Autores como John Chilton, Robert O’Meally, Donald Clarke, Stuart Nicholson, Farah Jasmine Griffin o John Szwed han emprendido esta tarea siguiendo la estela dejada por Lady Sings the Blues, la supuesta autobiografía escrita por la artista en compañía del periodista William Dufty y publicada en 1956. Su autenticidad y contemporaneidad la convirtieron en el referente literario esencial para desarrollar una aproximación a las vivencias, experiencias y sentimientos de la artista explicados como el relato de una mujer masoquista, dependiente y drogadicta.

En 1972 Sidney J. Furie realizaría una adaptación cinematográfica de esta autobiografía en el primer biopic de la historia del cine sobre una mujer cantante interpretada por Diana Ross como una persona débil, temerosa y frágil que abusa de la heroína y que necesita ser constantemente rescatada por una figura masculina. La secuencia de los títulos de crédito ya advierte sobre la caracterización del personaje dado que muestra a Billie Holiday en un estado físico y anímico deplorable, arrestada y encarcelada durante su proceso de desintoxicación. No es de extrañar que Oliver Nelson, un amigo de la artista y músico encargado de componer la banda sonora, abandonara el proyecto y que Artie Shaw se negase a que su nombre apareciese en la historia (Andújar, 2010: 38)

El libro que problematizará esta interpretación de la historia de la cantante será Con Billie Holiday: una biografía coral (2007) escrito por Julia Blackburn y estructurado en capítulos que toman la forma de una serie de entrevistas con sus más allegados. El texto complica la visión que se tenía sobre la dependencia emocional de Holiday hacia sus maltratadores rescatando citas como la siguiente: «(...) necesito un hombre que sea un hombre, y necesito un hombre que me lo recuerde una y otra vez. Si gano más dinero que él y soy más famosa que él, para afirmar su masculinidad me pega, me abofetea» (2007: 231). Del mismo modo, se cuestionan los juicios emitidos sobre la drogodependencia de la cantante cuando Blackburn afirma que (ib.: 242) William Dufty acordó con los editores que el abuso de la heroína sería el gancho para que el libro se vendiese.

En el siguiente artículo explicaremos el proceso que configura la producción y reproducción de esta imagen estereotipada de Billie Holiday que llega hasta nuestros días partiendo de la deconstrucción de los principios racistas y machistas que intervienen en la conformación de la identidad racializada y engenerizada de la mujer afroamericana y que influyen en la significación de sus productos culturales. Con tal propósito investigaremos los personajes y las canciones que interpreta Billie Holiday en el cortometraje musical Symphony in Black (Fred Waller, 1935) y en la película New Orleans (Arthur Lubin, 1947). Estas apariciones cinematográficas serán tomadas como huellas del ejercicio de representación del poder y como espacios de negociación del conflicto entre lo popular y lo masivo que desestabilizará la significación de lo negro impuesta por el status quo.

\section{Discurso, poder y colonialismo: la racialización y engenerización de lo negro}

A lo largo de siglos y siglos de historia, los procesos de construcción de las identidades racializadas dicotómicamente diferenciadas han buscado el mantenimiento de la posición de privilegio del hombre blanco. Para ello la «negritud», entendida como la subjetividad afroameri- 
cana que construye y es construida en las experiencias, placeres, recuerdos y tradiciones compartidas por el pueblo afrodescendiente, ha sido vaciada de significado y utilizada para la diferenciación de la «identidad racial» blanca (Yost, 2008: 1315), que invisibiliza su color de piel estableciéndose como el paradigma de la normatividad racial (Braidotti, 2004: 211).

La lógica dicotómica y maniquea de la racialización tiene su origen en una serie de prácticas y discursos articulados desde el inicio del sistema colonial que configuran al Otro como una imagen-espejo de Europa a través de la disolución de las diferencias entre los individuos colonizados en un único ser deshumanizado (Hall, 2013: 92-93), inferior a los hombres blancos anatómica e intelectualmente y dotado de una libidinosidad incontrolada (Shohat y Stam, 2002: 152-153). Esta animalización e infantilización del colonizado servirá como punto de contraste para conformar la identidad burguesa de hombres y mujeres blancas.

En el caso de los hombres afroamericanos, la consideración del negro como ser fobógeno, es decir, un ser que despierta terror y admiración sexual por la creencia infundada en su enorme pene (Fanon, 2009: 143-144), motivará la emergencia del mito del violador negro (Davis, 2005: 183) y convertirá al hombre blanco europeo en un «sujeto/agente, apto para gobernar, para la vida pública, un ser de civilización, heterosexual, cristiano, un ser de mente y razón» (Lugones, 2010: 106).

Por su lado, las mujeres afroamericanas fueron caracterizadas como figuras promiscuas y agresivas con el objetivo de disculpar los abusos cometidos (Lugones, 2008: 96-97; Davis, 2005: 25) y constituir el afuera constitutivo del ideal de feminidad caracterizado por la pureza sexual, la pasividad y la domesticidad (Lugones, 2010: 106). En esta línea, Mercedes Jabardo identifica tres imágenes estereotipadas de la mujer negra en la cultura dominante, a saber (2008: 44): la jezzabel, una mujer dedicada a la prostitución que vive una vida llena de excesos desencadenantes de su trágico final; la mammy, la criada doméstica buena y sumisa que sirve como sustituta de la madre blanca sin experimentar sus privilegios; y la matriarca, una mujer fuerte que trabaja todo el día fuera de casa para poder mantener a su familia y no es capaz de tener relaciones emocionales estables. Estos estereotipos se interrelacionan en beneficio de la explotación económica de la institución esclavista que conecta el apetito sexual excesivo con la obligación maternal de nutrir emocionalmente a niños y padres blancos (Collins, 2000: 81-82).

La inferiorización de las mujeres afroamericanas tanto por su género como por su color de piel hizo de ellas un sujeto invisible cuyas demandas no se correspondían ni con el movimiento negro ni con el movimiento feminista. Este último cayó en la lógica dicotómica categorial equiparando la categoría «mujen» a la de «mujer blanca» (Lugones, 2008: 95), debido a lo cual expulsó fuera de su agenda las preocupaciones de las mujeres trabajadoras o de color. Ante la introducción de una jerarquía racial dentro del feminismo blanco (Davis, 2016: 325), Sojourner Truth alzará la voz para demandar la necesidad de una lucha interseccional contra la dominación sexista y racista presente en la experiencia diaria de las mujeres racializadas:

\footnotetext{
Yo he arado, he sembrado y he cosechado en los graneros sin que ningún hombre pudiera ganarme, ¿y acaso no soy una mujer? Podía trabajar tanto como un hombre, y comer tanto como él cuando tuviese la comida y, también, soportar el látigo, ¿y acaso no soy una mujer? He dado a luz a trece niños y he visto vender a la mayoría de ellos a la esclavitud y cuando grité, con mi dolor de madre, nadie sino Jesús pudo escucharme, ¿y acaso no soy una mujer?
}

(Davis, 2005: 69)

Junto a esta y otras pioneras del movimiento feminista negro, las mujeres del blues clásico de los años veinte como Gertrude Ma Rainey, Bessie Smith o Ida Cox jugarán un papel clave en la toma de conciencia política de las mujeres afroamericanas. Sus canciones despliegan referencias constantes al ejercicio de la libertad sexual y de movimiento obtenido tras el fin de la esclavitud cosa que sirve para replantear las nociones hegemónicas de amor, sexualidad y domesticidad adscritas a su género (Davis, 1988: 10-11), articulando así un lenguaje de resistencia que intentará ser neutralizado por el discurso hegemónico con su calificación como 
jezzabel (Jabardo, 2012: 41-42). Una suerte similar sufrirá la música de Billie Holiday, que bebe del legado feminista negro de las mujeres del blues pero también se adscribe a las canciones de desamor producidas y distribuidas por la industria cultural de la época.

\section{Entre lo popular y lo masivo: conflicto y negociación en las interpretaciones musicales de Billie Holiday}

La música ha sido definida por la antropología y la sociología como una práctica social (Méndez, 2016:17), una experiencia comunicativa que participa en la construcción de las identidades individuales y colectivas y por ende uno de esos lugares donde las categorías de raza y género son enseñadas y debatidas (Tucker, 2004: 8). En el contexto estadounidense, el sistema esclavista impuso una prohibición en cualquier forma de creación artística manifiesta a excepción de la música (Davis, 2016: 63-64), por lo que esta tendrá un papel fundamental en forjar una herencia cultural compartida $y$, por encima de todo, en criticar la opresión racista de forma silenciosa o inadvertida (Sullivan, 2011: 31) a través del uso de un lenguaje polisémico que trasciende el significado literal de lo dicho para expresar ideas de rebelión. Por esta razón, la música negra desarrolla una significación en la que no hay una correspondencia exacta entre las palabras y los objetos a los que hacen referencia (Davis, 1998: 166).

El repertorio musical de Billie Holiday se ha situado tradicionalmente en el jazz clásico, aunque Angela Davis va más allá y ubica esta figura en un espacio intermedio entre el legado que habían dejado las mujeres negras del blues de los años veinte y las canciones de desamor interpretadas típicamente por cantantes blancas, lo que confiere a su música un significado muy peculiar:

She was able to rescue for her own ends the very elements of that culture that might have devoured her talents and her identity. Because she brought an original version of popular song to the world at the same time expanded the world of jazz, she communicated critical social meaning-across racial and class boundaries- to the populations, and especially to the women, of both worlds.

(Davis, 1998: 172)

Quizás la canción que mejor ejemplifica su compromiso político sea Strange Fruit, en la que hace uso de la metáfora visual de un extraño fruto que cuelga de los árboles sureños para hacer referencia al cadáver de un hombre afroamericano víctima de un linchamiento ${ }^{1}$. Sin embargo, se considera que Billie Holiday no sabía a qué se refería el contenido de la canción porque se salía de su repertorio habitual de canciones románticas que el discurso hegemónico significaba como autobiográfico para poder convertirle en víctima o jezzabel. En esta línea, Stacy Holman Jones critica los presupuestos en los que se basa la obligatoriedad confesional que se ha impuesto al repertorio de Holiday de la siguiente manera:

Holiday's performances are supposed to be confessional, offering testimony about her life. As testimony, the confessional of torch is grounded in the realist, humanist belief that a singer can tell the truth about herself and, further, that there is an essential and stable "Billie" to be narrated and preserved in the music. More, Holiday's "life" story must correspond with the story told in the auto/biography and the story told in the music.

(Jones, 2010: 284)

Jones apunta a la existencia de una distancia performativa o un espacio de la performatividad que permite que la cantante se separare de aquello que narra y ofrezca una crítica del miedo y la violencia ejercidos contra las mujeres a su público mayoritariamente femenino (2010: 285). Esta distancia únicamente habría sido reservada a los hombres, los cuales pueden separar lo que cuentan sus canciones de su vida real sin perder su autenticidad (2010: 286).

Todo ello se revela como fundamental para el análisis de las interpretaciones musicales de Billie Holiday en el contexto cinematográfico, concebidas como espacios

\footnotetext{
${ }^{1}$ Por aquel entonces el linchamiento era una práctica consuetudinaria en virtud de la cual una multitud de vecinos estaba autorizada a apoderarse de una persona sospechosa de haber cometida un delito, juzgarla, condenarla y ejecutarla en el acto, que no fue criminalizada hasta el final de la Segunda Guerra Mundial.
} 
de lucha entre la función social que despliega su crítica silenciosa a la misoginia de la época y las convenciones ideológico-culturales establecidas con su entrada en el circuito mediático (Frith, 2008: 433). Sin embargo, este conflicto no contará con una resolución clara, sino que tendrá como consecuencia la aparición de formas culturales híbridas en las que encontraremos la expresión de un pueblo junto a su deformación mediática. Stuart Hall lo explica del siguiente modo:

Las formas en las que la gente y las comunidades negras, y sus tradiciones aparecen y son representadas en la cultura popular, son deformadas, incorporadas e inauténticas. Sin embargo, seguimos observando, en las figuras y repertorios de que se nutre la cultura popular, las experiencias que están detrás de ellas.

(Hall, 2010: 291-292)

En estas luchas, interacciones y negociaciones entre lo popular y lo masivo debemos situar la historia de la representación cinematográfica de los productos culturales afroamericanos en la primera mitad del siglo XX, y más concretamente, las apariciones cinematográficas de Holiday en Symphony in Black (Fred Waller, 1935) y New Orleans (Arthur Lubin, 1947).

\section{La representación cine- matográfica hollywoodense de Billie Holiday}

\subsection{El cine estadounidense de los primeros tiempos: la conformación de una imagen fílmica de la "negritud"}

El filósofo postestructuralista Louis Althusser definió (1974: 23-24) los medios de comunicación de masas como aparatos ideológicos del Estado por su utilización de la ideología como principal herramienta para reproducir el status quo racista y sexista, y asegurar así el mantenimiento de la hegemonía de la clase dominante. A diferencia del uso de la fuerza para la reproducción de las relaciones de producción, el funcionamiento de la ideología responde a un sistema de representaciones mediante las cuales los individuos se relacionan con sus condiciones materiales de existencia (ib.: 43), por lo que su uso permite intervenir en el proceso de constitución del individuo como sujeto (ib.: 54).

En el caso concreto del cine, la configuración de una serie de posiciones de identificación a las que se convoca al espectador y a las que debe adherirse a través de su mirada para dotar de significado al flujo de imágenes en movimiento, tiene el objetivo de convertir al espectador en sujeto de la enunciación (De Lauretis, 1992: 216), un sujeto sujetado a las imágenes de la pantalla que si bien es capaz de ver y saberlo todo, se encuentra en un estado en el que es fácilmente influenciable (Amount et al, 1989: 265).

Empero, esta posición de sujeto de la enunciación no es neutra, puesto que los juegos de miradas que articula el dispositivo a la pantalla intentan introducir y reproducir las jerarquías de género y sexuales del contexto histórico en el que emergen. Por este motivo, Laura Mulvey consideró que el cine narrativo hollywoodense era un espectáculo erótico para los hombres que configuraba a las mujeres como objeto de la mirada y de deseo del espectador y de los personajes (2007: 86), al mismo tiempo que las significaba como una amenaza de castración que debía ser erradicada mediante procedimientos como el voyerismo sádico o la escoptofilia fetichista (ib.: 88-89).

Asimismo, la asimetría en el poder de mirar se puede aplicar a la representación cinematográfica de la población afroamericana. En los primeros diez años de andadura del cine en Estados Unidos, la aspiración a captar la cotidianidad permite a los afroamericanos aparecer en la gran pantalla en papeles menos degradantes que los que se habían consolidado en el teatro (Cripps, 1993:7). A medida que se instaure el modo de representación institucional, heredero de formas racistas de teatro popular y basado en el compromiso con la subjetividad espectatorial que no puede verse alterado por la aparición de personajes racializados con los que el espectador se pueda identificar, la presencia de 
los afroamericanos quedará reducida a la interpretación de personajes fuertemente estereotipados, secundarios, cómicos y que se dedican a servir a los blancos y/o al mundo del espectáculo (Knapp, 2009: 79).

Uno de los procedimientos más frecuentes para representar la «negritud» estereotipada será el blackface, una técnica de maquillaje teatral elaborada con corcho quemado que utilizaban los actores blancos del espectáculo del minstrel show para imitar lo negro de forma caricaturesca. La mascarada actuaba como soporte fetichista de los estereotipos asociados a los afroamericanos y desarrollaba la ambivalencia del discurso sobre la otredad que manifestaba un deseo de incorporación y una negación de la misma, pues este maquillaje permitía convocar metonímicamente la negritud y ausentarla en su representación (Modleski, 1995: 113-114).

Del mismo modo, Eric Lott (2013: 167) plantea, en su estudio sobre el uso del blackface en los espectáculos del minstrel show en la época anterior a la guerra civil estadounidense, que en la encarnación de la «negritud» masculina encontramos una castración burlesca motivada por el miedo al mestizaje interracial y un deseo homoerótico de posesión del primitivismo adscrito al mismo. Por el contrario, el autor afirma que en el caso de la encarnación de las mujeres afroamericanas por parte del hombre blanco no existe tal deseo sino únicamente una ridiculización que frene la amenaza que aúna lo negro con lo femenino (ib: : 156-157).

La mascarada racial fue utilizada en las películas del cine de los primeros tiempos independientemente de si la película presentaba una historia proabolicionista, como la adaptación de Edwin S. Porter de La cabaña del tio Tom (Uncle Tom's Cabin, 1903), o de si se trataba de poner en escena una epopeya de la Guerra de Secesión y la Reconstrucción estadounidense como hizo David Wark Griffith en El nacimiento de una nación (The Birth of a Nation, 1915). Posteriormente, la sonorización puso fin a la interpretación de papeles dramáticos en blackface pero revivió el uso del mismo en los minstrel show (Rogin, 1994: 4), llegando a ser un sello de las interpretaciones de actores famosos de musicales de los años treinta y cuarenta como Al Jolson o Eddie Cantor.

\subsection{El cine musical hollywoodense de los años treinta y cuarenta: apropiacionismo y blanqueamiento de las prácticas culturas afroamericanas}

En los primeros años de historia del aparato fílmico, las imágenes cinematográficas se mostraron en silencio de forma excepcional puesto que lo más habitual era que tuvieran un acompañamiento musical para aislar al espectador de los ruidos que podían haber en la sala (Burch, 1991: 233-234). El ragtime, uno de los padres del jazz, será de los primeros géneros musicales que servirá para construir esta atmósfera envolvente. Poco a poco, en un esfuerzo porque la música se integre a lo narrado, sus melodías sincopadas se reservarán únicamente a escenas de fiestas y bares (Musser, 1978: 1).

Tras la finalización de la Primera Guerra Mundial, el gusto cambia hacia otro estilo de jazz más descarado procedente de las bandas de Jerry Roll Morton, King Oliver o Louis Armstrong y adquiere tal popularidad que las productoras cinematográficas se apresuran a realizar películas con temática jazzística (ib.: 2), entre las cuales destaca El cantor de jazz. (The Jazz Singer, Alan Crosland, 1927) posiblemente por ser uno de los primeros intentos de incorporar la tecnología del sonoro al espectáculo fílmico a través de efectos de sonido ocasionales y una banda musical sincronizada con posterioridad. La película cuenta la historia de Jakie Rabinowitz (Al Jolson), un cantante judío de vodevil que utiliza la mascarada racial en sus interpretaciones de música ragtime para ocultar su verdadero rostro y así huir de las reprimendas de su padre.

Más allá del impulso que el éxito de taquilla proporcionó a la industria cinematográfica para emprender su proyecto de sonorización (Andújar, 2011: 388), es interesante subrayar que The Jazz. Singer perpetúa la utilización del travestismo racial como mecanismo ambivalente de diferenciación e identificación con la otredad racializada y con lo que esta significa (Rogin, 1992: 1052). Además, en el contexto musical esto supone la 
inserción de un mecanismo autorreflexivo sobre la naturaleza artificiosa del fetiche y sobre las formas teatrales racistas sobre las que se erige el entretenimiento musical hollywoodense (Rogin, 1994: 3).

En la década de los años treinta y cuarenta, la expansión de la utilización de la mascarada racial ocasiona la expulsión de los afroamericanos de la gran pantalla o, en el mejor de los casos, su aparición como personajes secundarios (Cripps, 1993: 254) ubicados dentro de secuencias diseñadas como atracciones autosuficientes para no tener que lidiar entre el conflicto que supone la integración de lo negro y la capitalización de su popularidad (Merrel, 1978: 3). En este sentido, Shohat y Stam critican el doble discurso de la representación de la «negritud» con las siguientes palabras: «En una contradicción derivada del reparto de poder, la misma sociedad dominante a la que le "encantan" los fragmentos ornamentales de la cultura negra, luego excluye a los intérpretes negros, que serían los más adecuados para personificarlos» (2002: 226).

Una de las películas que mejor reflejaba esta situación fue El rey del jazz. (King of Jazz, John Murray Anderson, 1930). Protagonizada por el afamado músico de jazz Paul Whiteman, el filme hace un recorrido pedagógico, blanqueado y masculinizado por la historia del género con la intención de subrayar el papel de Whiteman en la transformación de esta música de raíces primitivas, africanas y esclavas en una forma de arte elevado típicamente estadounidense (Rogin, 1992: 1064). En la década de los cuarenta, esta degradación de lo negro se combatirá con una revalorización de los orígenes y músicos afroamericanos en musicales como Una cabaña en el cielo (Cabin in the Sky, Vincente Minnelli, 1943) y Stormy Weather (Andrew L. Stone, 1943), aunque continuarán produciéndose musicales de carácter apropiacionista sobre la historia del jazz blanqueada o sobre la vida de músicos blancos que señalan la creencia implícita de que los blancos son mejores en la música y en el baile que sus creadores e impulsores (Dyer, 2002: 43).

A parte de los largometrajes, en estos años encontramos imágenes altamente estereotipadas de la «negritud» en películas de animación y cortometrajes musicales ${ }^{2}$. Ejemplo de ello es la película de dibujos animados I'll Be Glad When You're Dead, You Rascal You (Dave Fleischer, 1932) que pone en marcha la animalización, el primitivismo y el peligro atribuido al hombre negro y su música mediante un Louis Armstrong convertido en un caníbal salvaje que quiere devorar a Betty Boop y persigue a sus amigos Koko y Kimbo (Goldmark, 2005: 2). A su vez, I'll Be Glad... se había basado en el cortometraje musical A Rhapsody in Black and Blue (Aubrey Scotto, 1932), que utilizaba las mismas canciones y la misma imagen «jungle» de Armstrong proyectadas sobre una trama en la que un marido (Sidney Easton) hacía enfadar a su esposa (Fanny Belle DeKnight) a causa de su holgazanería hasta que esta se hartaba y reaccionaba dándole un golpe con una fregona (Cripps, 1993: 233).

Es importante subrayar para nuestro estudio que esta agresividad atribuida a la mujer afroamericana ya había aparecido en otras películas como St. Louis Blues (Dudley Murphy, 1929), un cortometraje musical en el que la cantante de blues Bessie Smith interpreta a una mujer temperamental que encuentra a su hombre, el bailarín de claqué Jimmy Mordercai, en compañía de otra mujer. Cuando Bessie se pelea con la otra mujer, Jimmy le abandona y para ahogar sus penas se da a la bebida mientras canta St. Louis Blues.

Como vemos a través de estos ejemplos, la imagen del hombre negro como poseedor de una sexualidad incontrolada que le impulsa a querer devorar a Betty Boop y a cometer infidelidades, y la imagen de la mujer como agresiva o como víctima de sus excesos que canta un blues para aliviar su mal de amores son personajes recurrentes insertados en un contexto de desprestigio de los orígenes negros y blanqueamiento de la música jazz. A continuación, trataremos de trazar las continuidades y discontinuidades que existen entre estas repre-

\footnotetext{
2 A parte de estos dos géneros, en esta época los afroamericanos aparecieron en las llamadas race movies, películas nacidas del deseo de luchar contra la imagen estereotipada de la negritud que se encontraban fuera de los circuitos comerciales habituales y que contaban con trabajadores exclusivamente negros. La insuficiencias técnicas e inexperiencia, los problemas de distribución y publicidad y el escaso interés que suscitaban entre el público provocaron que el proyecto acabara hundiéndose (Cripss, 1993: 5-6).
} 
sentaciones y en la recreación de la vida del Harlem que evoca el cortometraje Symphony in Black y la historia del jazz blanqueada que ilustra la película New Orleans.

\section{5. 'Symphony in Black' (Fred Waller, 1935) y 'New Orleans' (Arthur Lubin, 1947)}

\subsection{Symphony in Black: entre la misoginia y el desamor}

Symphony in Black es un cortometraje musical dirigido por Fred Waller y protagonizado por el afamado pianista Duke Ellington encargado de componer la epopeya musical Negro Moods en un discurso fundamentalmente visual que evita el diálogo a favor de la actuación y la danza. En este sentido, Symphony in Black es un filme pionero en presentar la figura de un negro como compositor de canciones de jazz sinfónico, un género de jazz formado por piezas musicales interpretadas por una gran orquesta en una sala de conciertos para un público respetable (Edwards, 2002: 15).

Esta sinfonía presenta cuatro movimientos que se corresponden con las cuatro partes del cortometraje: The Labourers, A Triangle, A Hymn of Sorrow y Harlem Rhythm. Los planos de Ellington en su estudio y los planos de su orquesta sirven de puente para conectar los diferentes movimientos asociados a determinados espacios y géneros musicales procedentes de la tradición popular afroamericana (fotogramas 1 y 2). En el caso de The Labourers (fotograma 3), el lugar elegido es una fábrica en la que trabajadores afroamericanos transportan carbón a altos hornos al ritmo de lo que parece una canción de trabajo. Posteriormente en $A$ Triangle, el swing y el blues servirán de acompañamiento a la historia del triángulo amoroso sucedida entre un piso y la calle suburbial del Harlem en el que se encuentra (fotograma 4). Más adelante, en A Hymn of Sorrow (fotograma 5) nos trasladamos a una iglesia en la que un sacerdote negro oficia el funeral de un niño haciendo uso de una canción espiritual, mientras que en Harlem Rhythm (fo- tograma 6) las imágenes se ubican en un club llamado Harlem Hot Spot donde los bailarines bailan al son de un jazz más picante.

La diversidad de narraciones y de espacios diegéticos interconectados es heredera de la estructura de los espectáculos de los años treinta de Duke Ellington, en los que era común realizar un recorrido geográfico y musical por la cultura afroamericana con el propósito de celebrar la sofisticación y la herencia musical de los afroamericanos modernos, que partía de los ritmos africanos, pasaba por la música del sur estadounidense y llegaba a las melodías del Harlem (Howland, 2008: 355). Del mismo modo, esta heterogeneidad parece apuntar a la función social y comunicativa de los productos culturales afroamericanos que emergen de la experiencia histórica de opresión racista. El mismo Ellington parecía ser consciente del poder de su música cuando en un artículo publicado en 1931 en la revista Rhythm afirmaba que:

\begin{abstract}
The music of my race is something more than the 'American idiom'. [...] It is the result of our transplantation to American soil, and was our reaction in the plantation days to the tyranny we endured. What we could not say openly we expressed in music, and what we know as 'jazz' is something more than just dance music.
\end{abstract}

(Edwards, 2002: 1)

Billie Holiday realiza su aparición en $A$ Triangle, un movimiento compuesto de tres partes, a saber: Dance, Jealousy y Blues. La secuencia se inicia con un plano de Ellington en su estudio tocando el piano que se une mediante un fundido encadenado a un travelling hacia atrás de Duke y su orquesta en una sala de conciertos (fotograma 7), que se conecta por corte directo a un plano de su trompetista (fotograma 8). A continuación, pasamos a un piso en una calle del Harlem en el que los bailarines Bessie Dudley y Earl «Snakehips» Tucker bailan al ritmo de la canción Ducky Wucky de Ellington (fotogramas 9 y 10). La joven Billie se encuentra situada fuera de la casa en una calle paralela desde la que contempla las sombras danzantes de la ventana del piso (fotograma 4). A la pareja se le hace tarde y decide salir de casa (fotograma 11), lo que provoca el inicio de la 


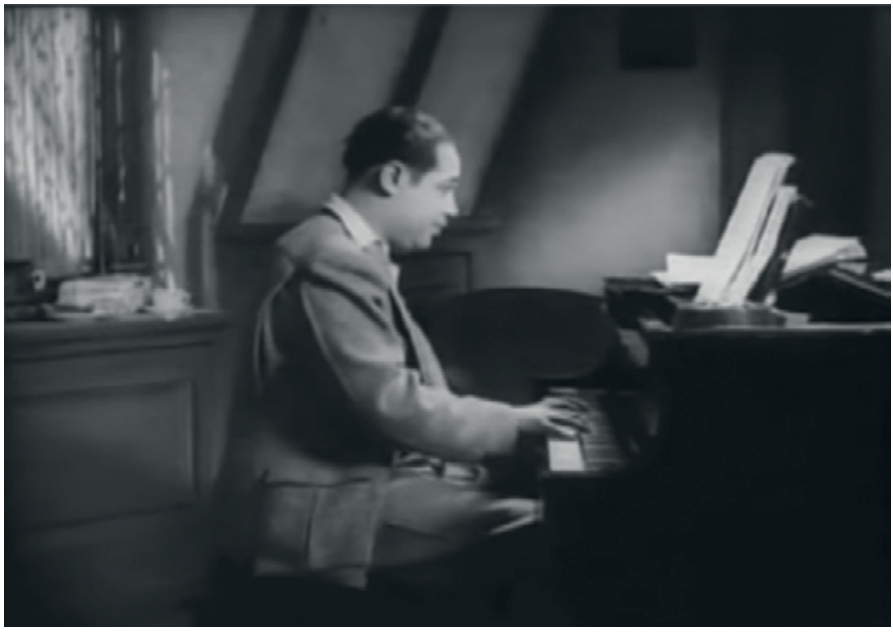

Fotograma 1

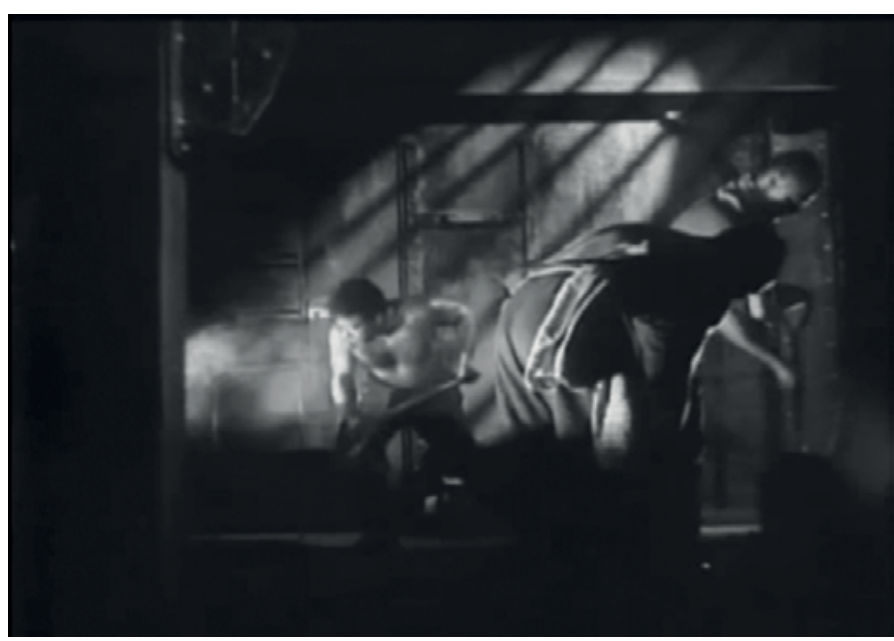

Fotograma 3

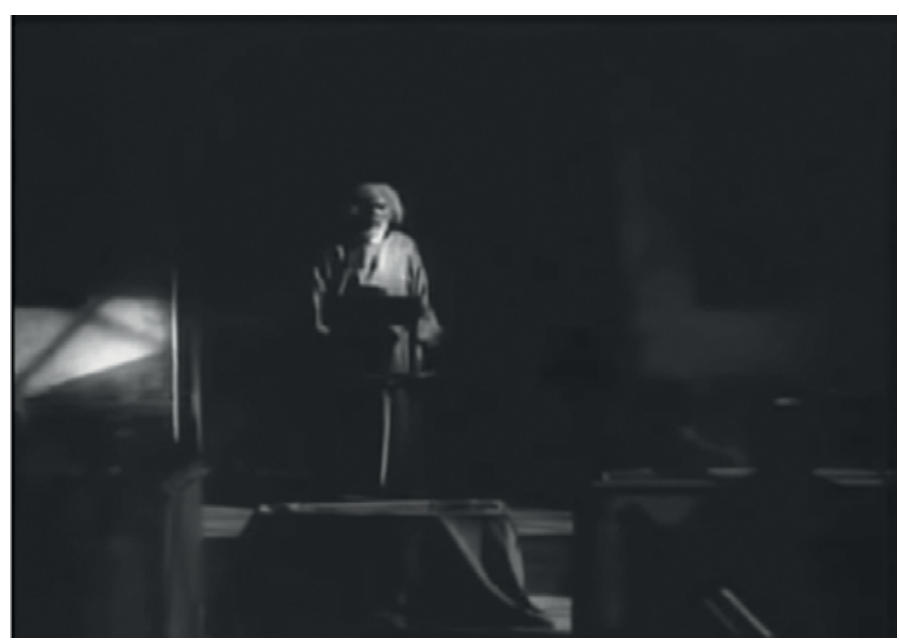

Fotograma 5

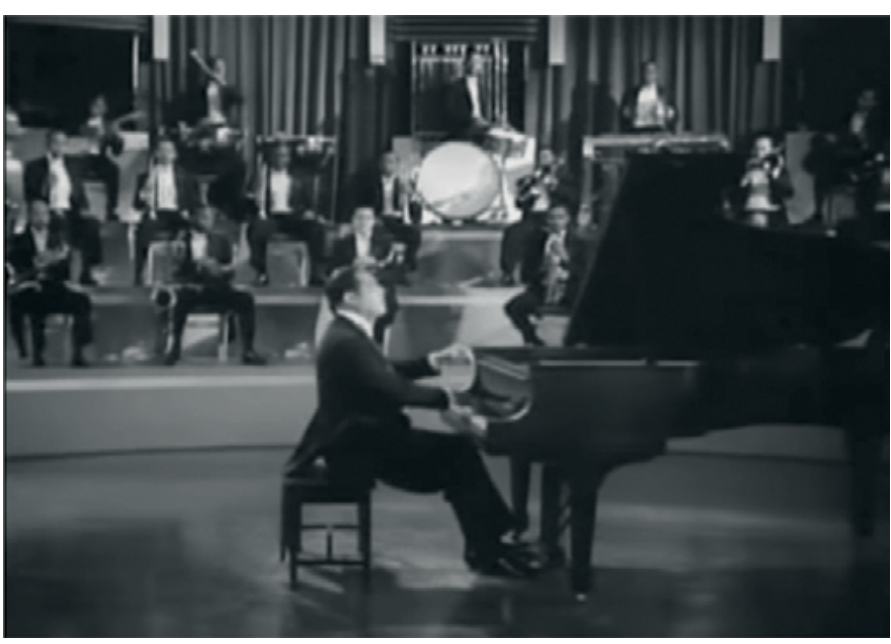

Fotograma 2

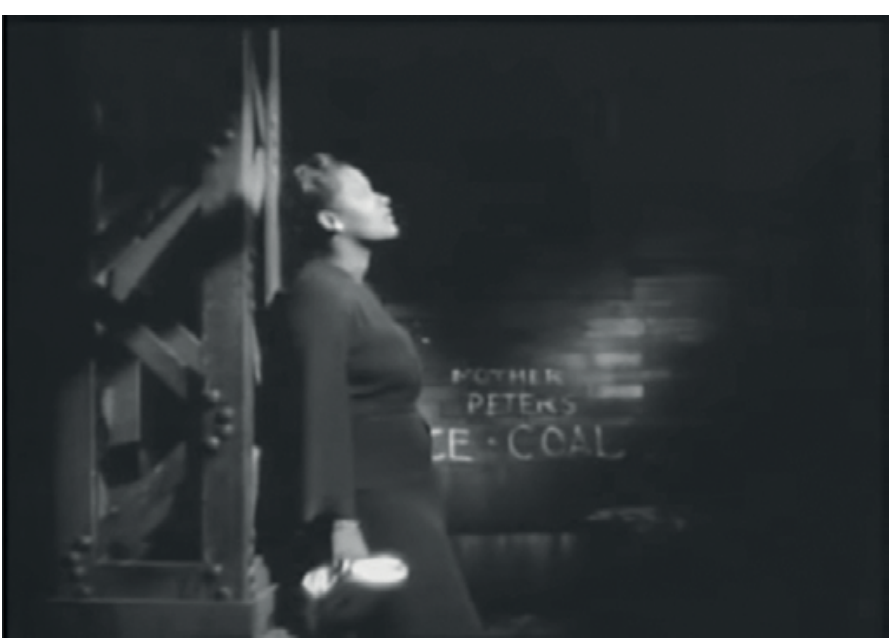

Fotograma 4

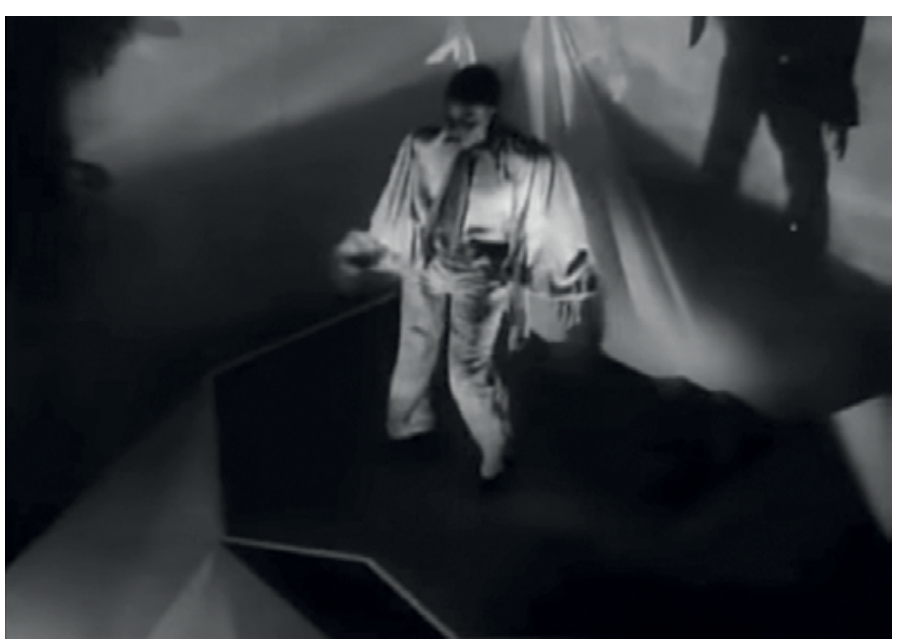

Fotograma 6 


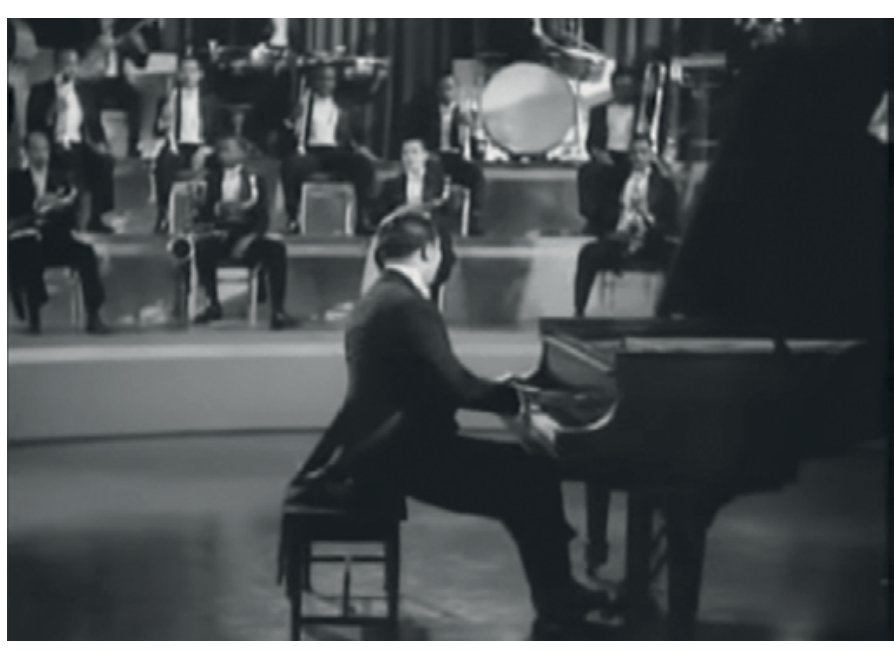

Fotograma 7

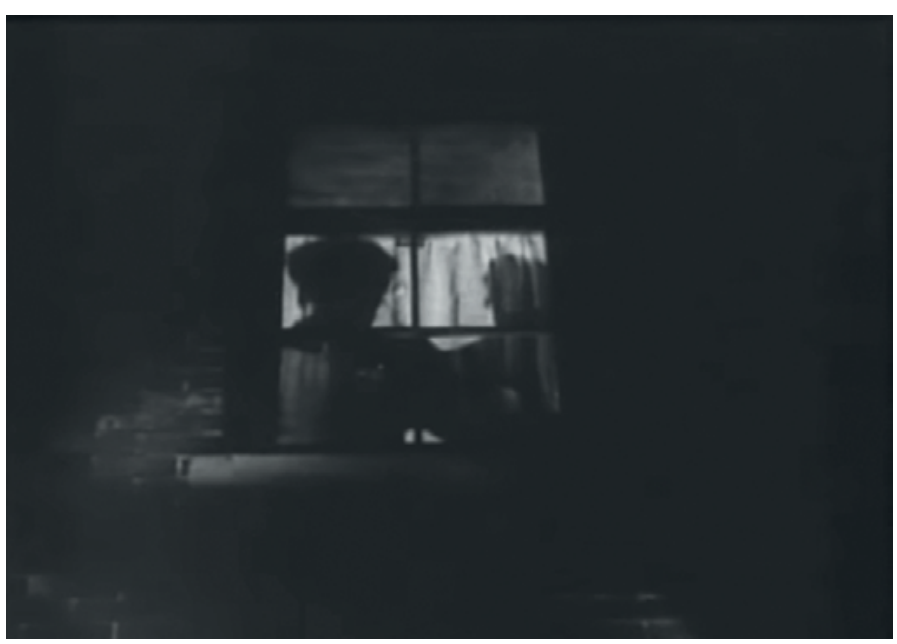

Fotograma 9

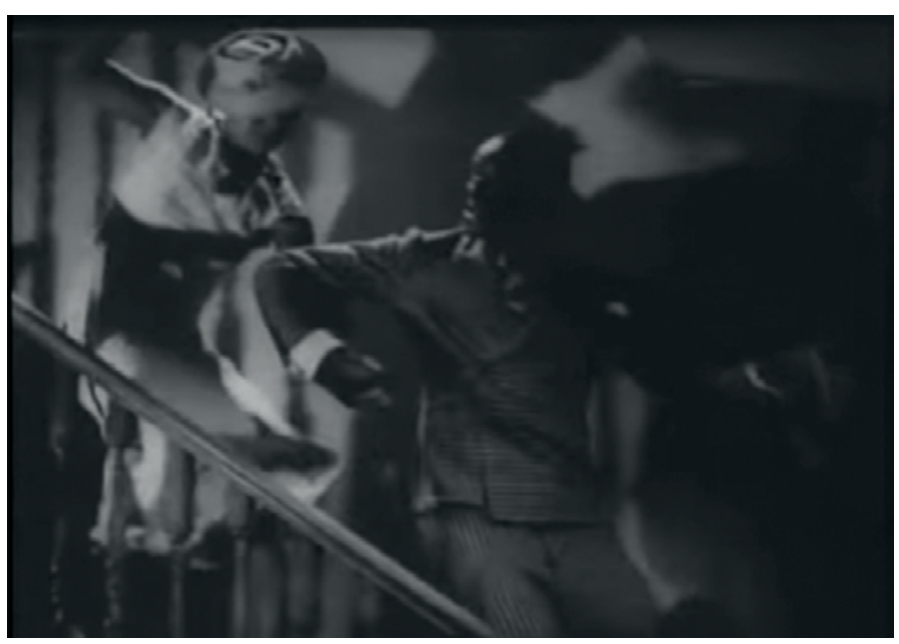

Fotograma 11

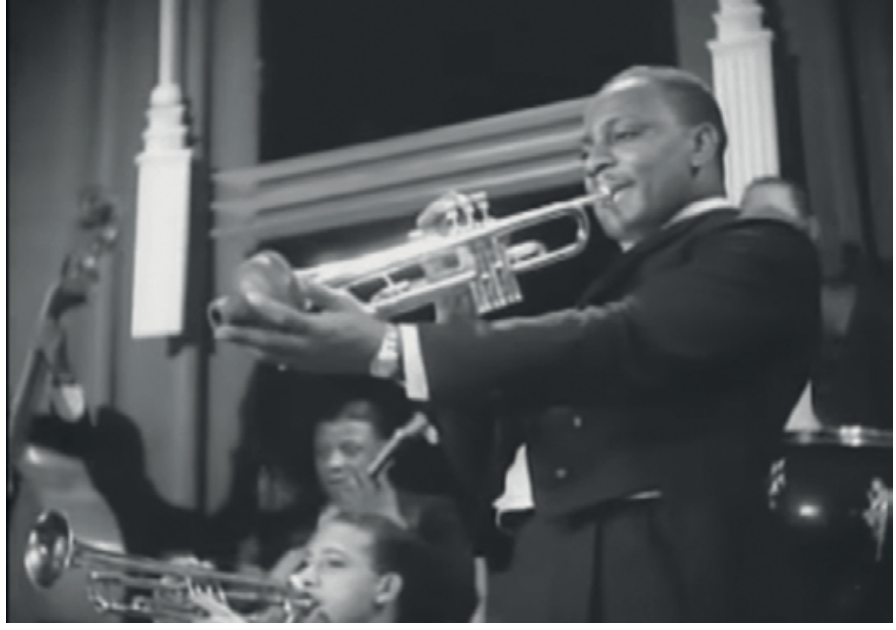

Fotograma 8

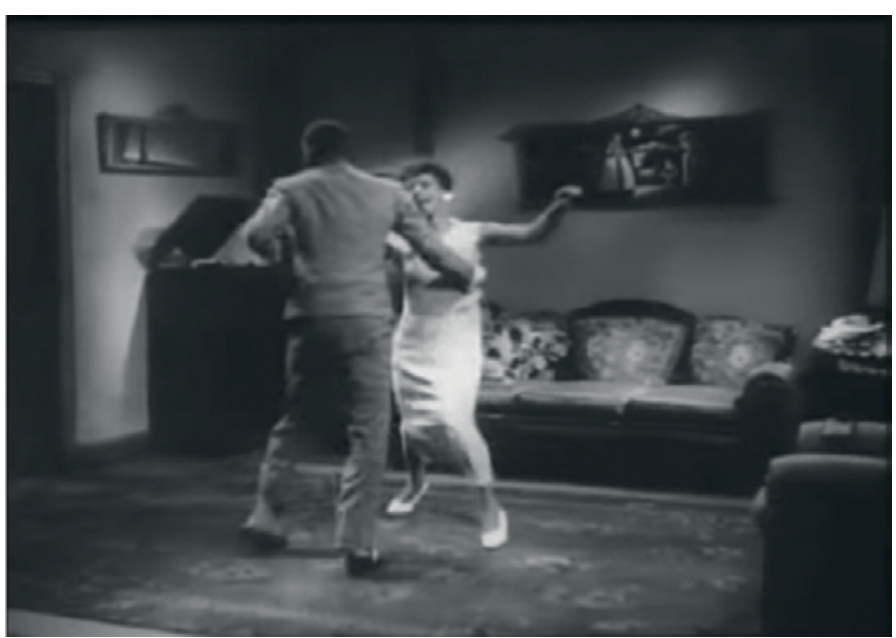

Fotograma 10

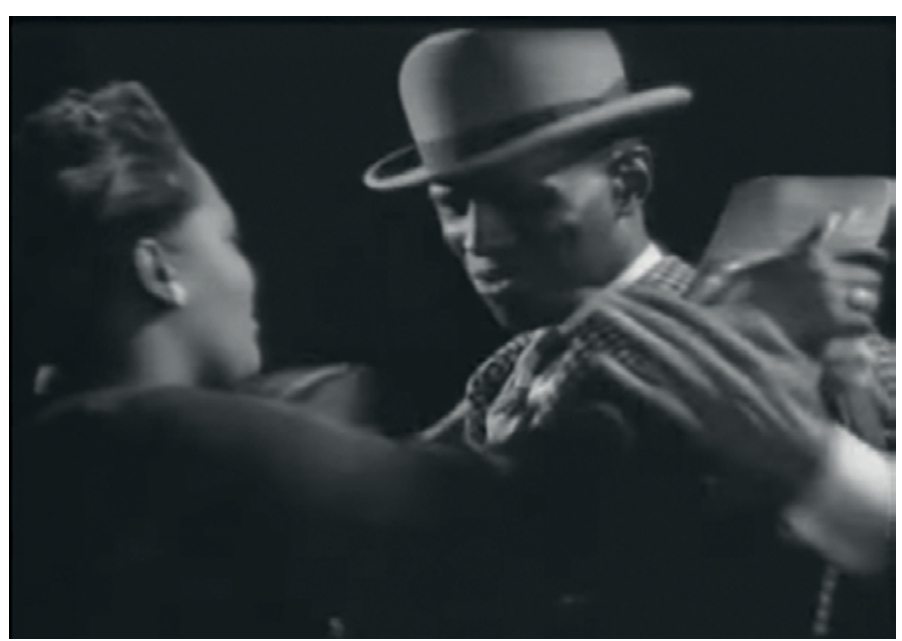

Fotograma 12 
segunda parte en la que Billie se topa con ellos e intenta retener a su antiguo hombre (fotograma 12), que reacciona arrojándole al suelo.

La tercera parte, tras volver brevemente al estudio y a la sala de conciertos, empieza con un plano contrapicado de Billie abatida en el suelo desde donde sin incorporarse canta Saddest Tale (fotograma 13). Seguidamente, pasamos a un plano del trombonista de la banda de Ellington en la sala de conciertos imitando el sonido de un lamento mientras se superpone el plano de la cantante incorporándose (fotograma 14). Por último, la cámara realiza un travelling hacia delante de la cantante recostada en un pilar (fotograma 15) hasta que finali-

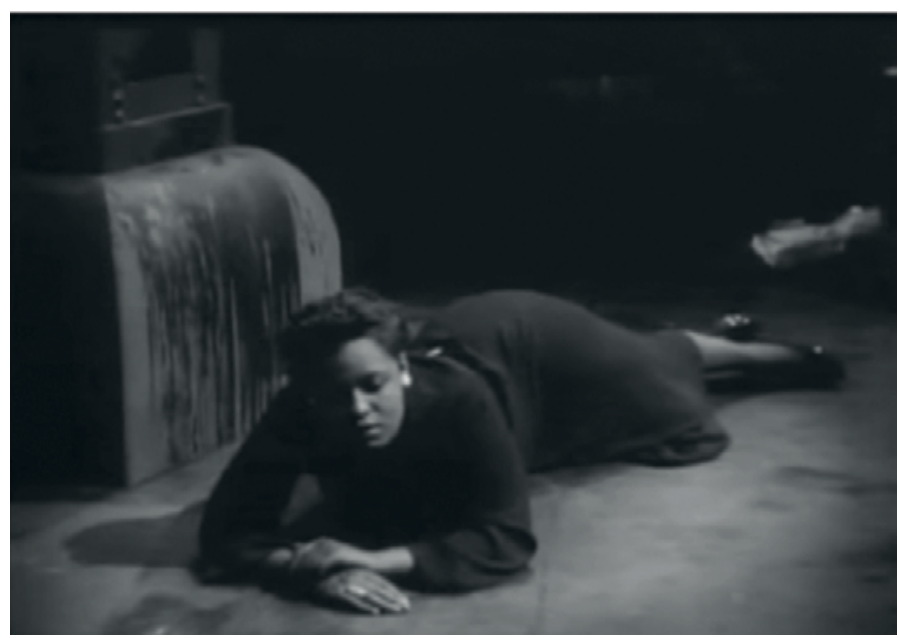

Fotograma 13

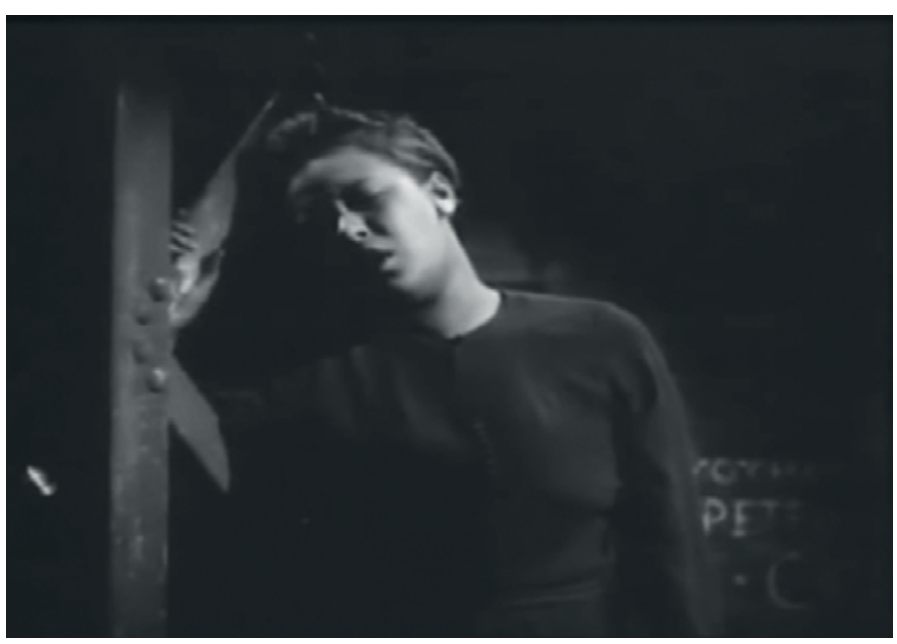

Fotograma 15 za su interpretación y se vuelve a la sala de conciertos (fotograma 16). En esta secuencia, el tratamiento de la interpretación de Holiday y la integración narrativa de Saddest Tale refuerza la idea que las mujeres vocalistas están obligadas a cantar biográficamente sobre sus desventuras amorosas, a diferencia de los hombres compositores y músicos que pueden aparecer interpretándose a ellos mismos.

En definitiva, Symphony in Black presenta un esfuerzo evidente para la elevación de la respetabilidad de Ellington, los músicos de jazz y los productos culturales afroamericanos y simultáneamente un uso de los estereotipos degradantes asociados a lo negro y utilizados para dra-

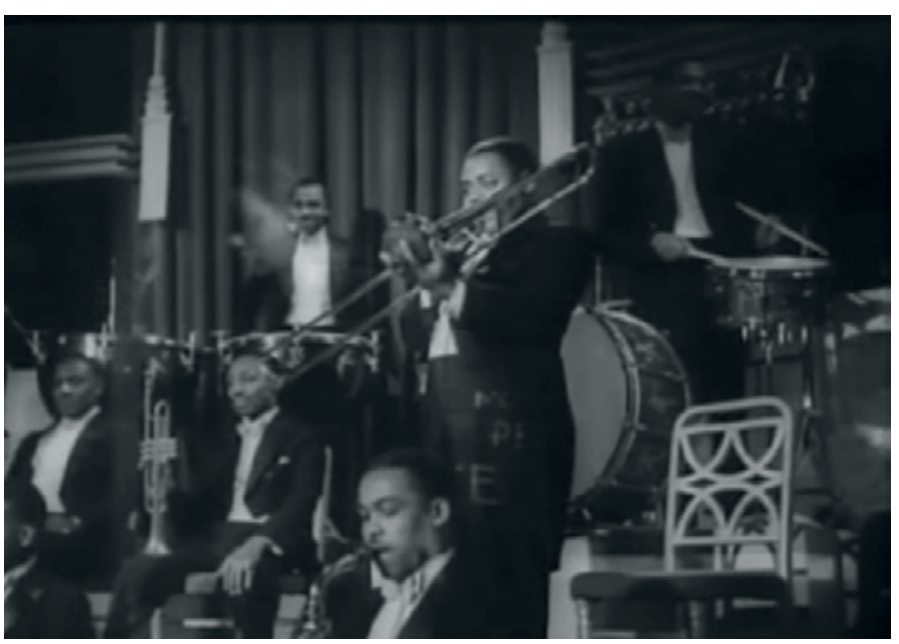

Fotograma 14

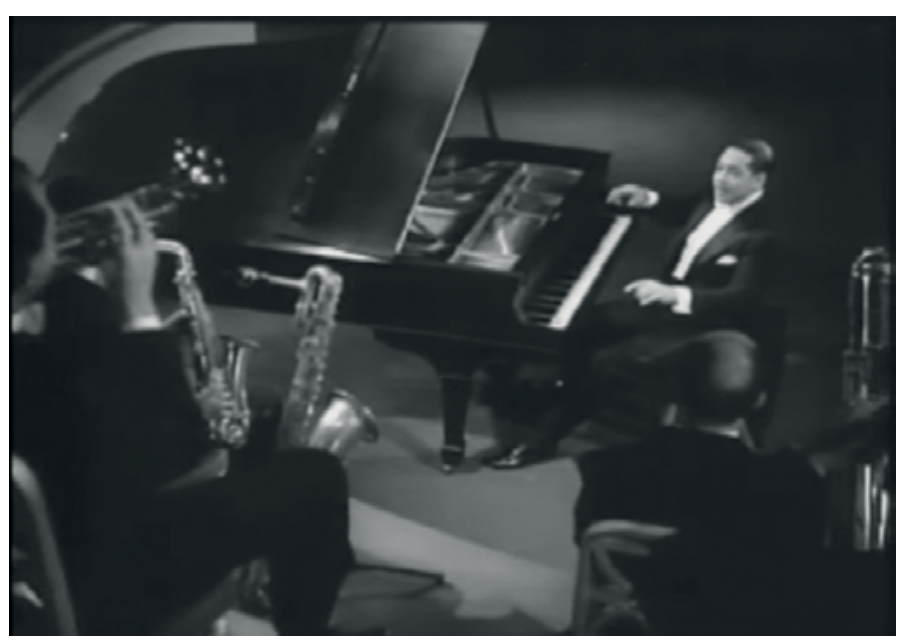

Fotograma 16 
matizar la experiencia cotidiana contemporánea de los afroamericanos. En concreto, observamos el recurso al hombre negro como poseedor de una sexualidad incontrolable que le impulsa a cometer infidelidades, posiblemente insinuadas mediante el baile (Moreno, 2007: 99), y de la mujer negra como agresiva y como víctima de sus excesos amorosos. No obstante, el lamento por el abandono del hombre de la canción Saddest Tale parece combatir estos prejuicios con un ejercicio de toma de conciencia de la misoginia de la época, que cuanto menos nos permitiría abrir la lectura de la representación de Billie Holiday e incluirla en la tradición afroamericana de formas de resistencia silenciosa.

\subsection{New Orleans: la apropiación del hogar perdido}

New Orleans es un largometraje musical dirigido por Arthur Lubin y guionizado por Herbert Biberman. La película narra la historia de amor entre Nick Duquesne (Arthur De Cordoba), dueño del local de jazz Orpheum Cabaret y rey del barrio de Storyville ${ }^{3}$, y Miralee Smith (Dorothy Patrick), una cantante de ópera en los albores de su estrellato. El correlato negro de dicha historia de amor es el romance entre Endie (Billie Holiday), la criada de Miralee, y Satchmo (Louis Armstrong), el líder de la orquesta del Orpheum.

Miralee llega a Nueva Orleans con el propósito de iniciar su carrera profesional y allí conoce a Nick que le introduce en el mundo de la música prohibida y de quien se enamora perdidamente. La madre de Miralee no aprueba su relación y decide poner fin al negocio del jazz, el juego y la prostitución de Storyville orquestando el cierre del barrio. El deseo de Nick de poseer a Miralee es el motor implícito de la narración que le impulsa a luchar por aumentar la respetabilidad de su negocio recurriendo a la figura de Woody Herman, compositor

\footnotetext{
${ }^{3}$ Uno de los focos de efervescencia cultural afroamericana fue Storyville, un barrio de Nueva Orleans creado en 1890 y clausurado en 1917 por una ley que prohibió la ejecución del negocio de la prostitución a menos de cinco millas de las bases militares.
}

de jazz blanco que trabajó en la banda sonora de la película. En este sentido, la cinta es un claro ejemplo de apropiacionismo cultural ubicado en la historia cinematográfica del jazz reducida a una serie de acontecimientos gestados por actantes blancos.

La apropiación de la música negra divide la narración en dos partes con un punto de giro definitorio vinculado al cierre de Storyville. La primera parte expone el deseo de conocer y aprehender la música negra por lo que predominan las incorporaciones de los músicos blancos en ambientes negros como es el caso de Henry Ferber, el líder de la asociación musical de Nueva Orleans y maestro de Miralee que se cuela a hurtadillas en el Orpheum Cabaret (fotograma 17). Contrariamente a lo que pudiera parecer, este deseo blanco de contacto íntimo con los productos culturales afroamericanos no elimina la jerarquización racial ya que la labor principal de lo negro es servir, entretener y aconsejar a los blancos. La segunda parte desarrolla la elevación de la posición social del jazz de modo que son los músicos negros los que aparecen en ambientes blancos como ocurre con Louis Armstrong y su banda (fotograma 18). Sin embargo, será la figura blanda de Woody Herman la que posibilite que el jazz y la ópera estén en el mismo nivel social y en el mismo escenario interpretando Do You Know What It Means To Miss New Orleans.

Dentro de las interpretaciones musicales del filme, la importancia de esta canción es evidente porque hace referencia al título de la película, es la banda sonora de los títulos de crédito y pone cierre al filme. La primera vez que la escuchamos es en casa de los Smith, donde Endie vestida con su traje de criada la canta al piano hasta que la madre de Miralee le interrumpe y le regaña diciendo que le tiene prohibido tocar esa «música del diablo». Toda la escena es mostrada desde el punto de vista de Endie (fotogramas 19 y 20) hasta que la cámara se queda con Miralee, quien quiere saber más cosas sobre ese tipo de música blues y le pide que acabe la canción (fotograma 21). El último plano de Endie cantando (fotograma 22) se funde con otro de Miralee cantando ópera en el salón de su casa prediciendo la 


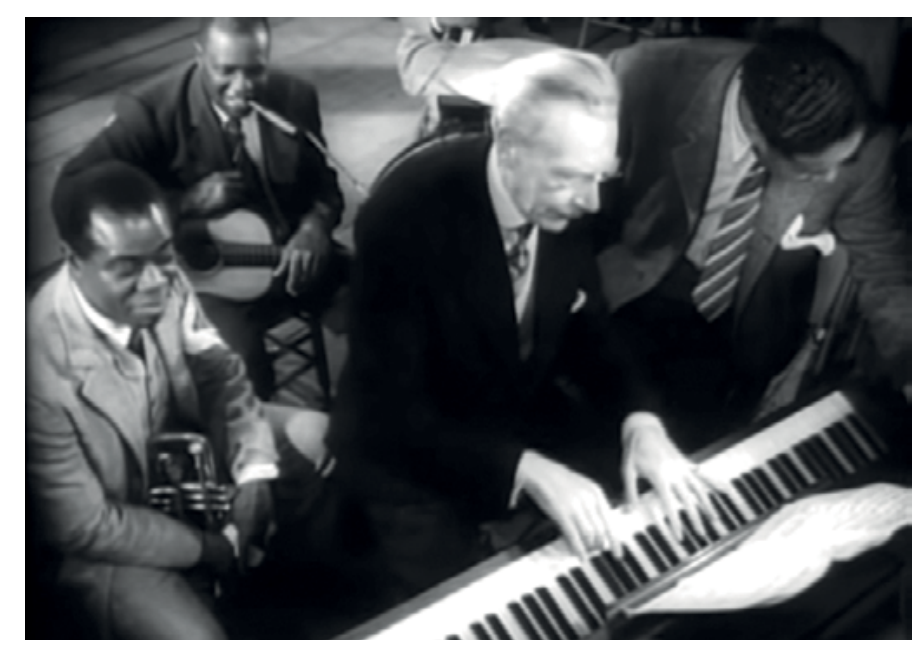

Fotograma 17

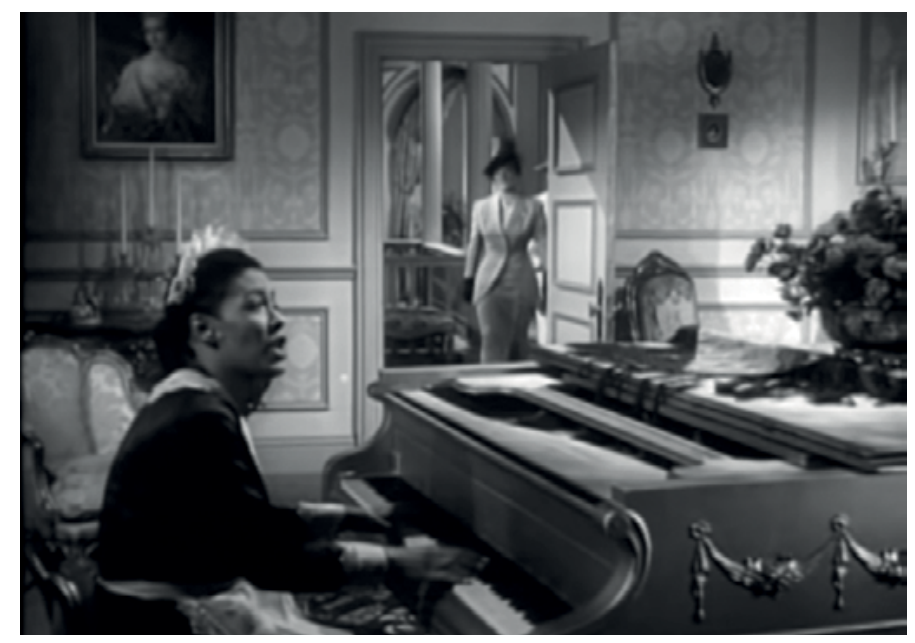

Fotograma 19

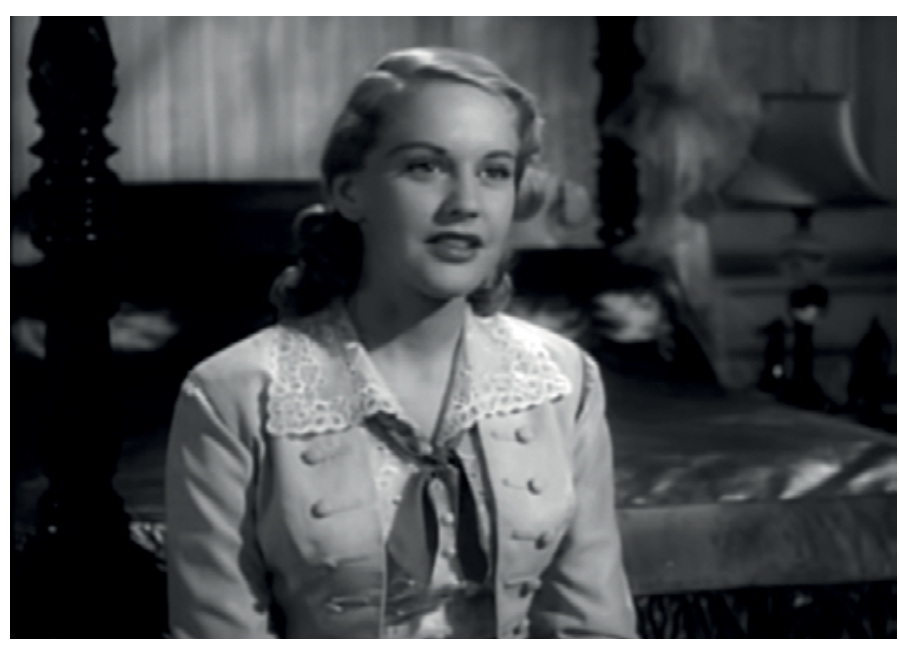

Fotograma 21

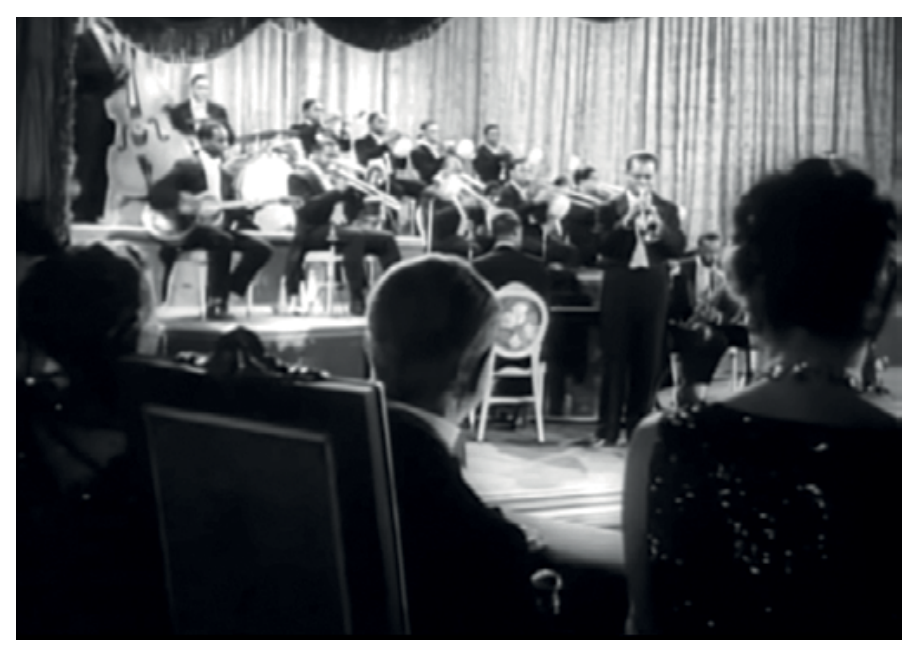

Fotograma 18

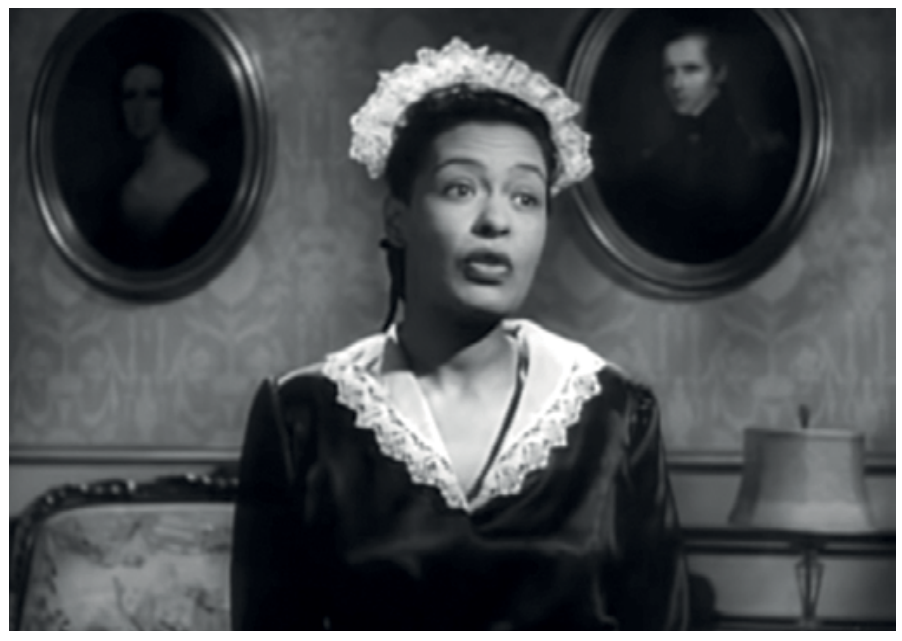

Fotograma 20

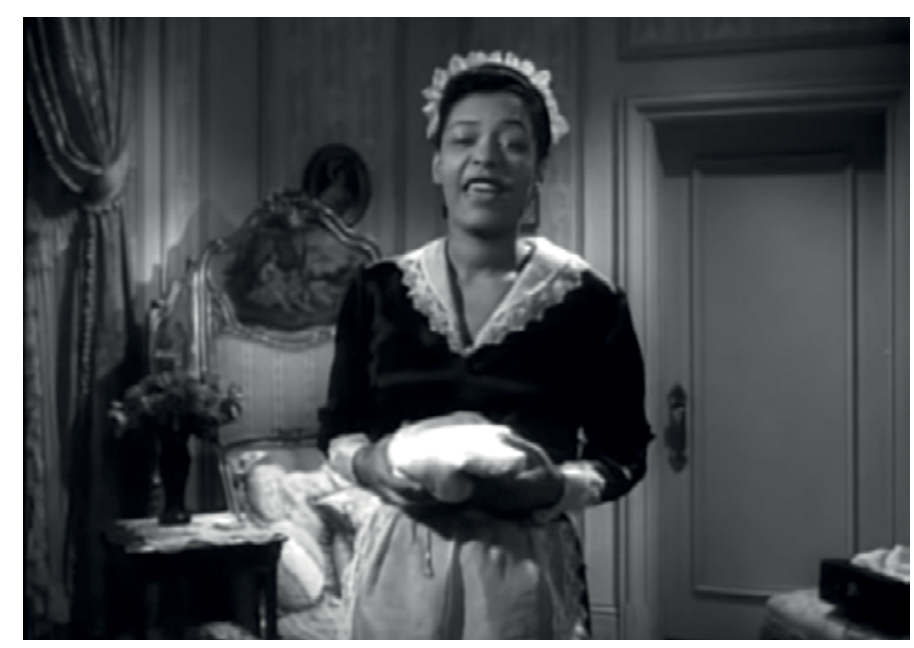

Fotograma 22 
operación de apropiacionismo que se va a ejercer sobre la canción escuchada.

La siguiente vez que Endie interpreta Do You Know What It Means... es en el Orpheum Cabaret junto a la banda de Satchmo en un número musical que articula un juego de miradas sobre el que se desarrolla el deseo y la operación de apropiación. Primeramente, tomamos el punto de vista de Miralee (fotograma 23) que mira a la banda, al señor Ferber y a Nick (fotograma 24) que le devuelve tímidamente la mirada (fotograma 25). El punto de vista de este último es el que se utilizará para mostrar a la banda (fotograma 26) y más adelante se unirá al de Miralee para conformar una única perspectiva de lo blanco (fotogramas 27 y 28).

En la versión negra, el significado de Nueva Orleans puede entenderse como un antecedente de la posterior inmigración que experimentan los afroamericanos en el filme tras el cierre del barrio de Storyville. Entonces, esta ciudad se podría conectar con el significado que las mujeres del blues clásico otorgaban al hogar sureño perdido como lugar de resistencia contra los abusos de los hombres blancos, el desmembramiento familiar y la reproducción forzada a la que se veían sometidas (Davis, 2016: 172). Sin embargo, la idealización del sur puede tomarse también como una estrategia de revalorización del pasado esclavista estadounidense practicada en formas teatrales populares en las que se presentaba una representación nostálgica y atemporal del sur caracterizada por una armonía interracial que disculpaba las atrocidades cometidas en la historia estadounidense (Lott, 2013: 208-209).

La mirada de Miralee en esta secuencia contiene una carga de excitación erótica derivada no solamente de la atracción que siente hacia Nick, sino fundamentalmente de la fetichización de lo negro, la asociación de lo negro con la criminalidad, la sexualidad y la impureza que produce un sentimiento de placer y peligro (Tucker, 2005: 13). Tras la interpretación de la canción, Miralee quiere conocer más sobre esta música cosa que le lleva a interrogar a Nick por sus orígenes y su respetabilidad, y fascinada llega a exclamar: «The music I've been singing, so traditional, it was new once. And I've been learning to make it mine. But this! This music is mine already.».
En esta línea, Sherrie Tucker argumenta que (2005: 2) la figura de Miralee es perfecta para poner en marcha el ejercicio de apropiacionismo del filme no solamente por su respetabilidad, sino precisamente porque su inocencia sobre su poder social le convierte en un agente inconsciente de racismo. Así, en la secuencia que pone fin a la película Miralee puede cantar sin remordimientos una versión operística de Do You Know What It Means... junto a la orquesta de Woody Herman en la sala de conciertos Symphony Hall.

A diferencia de lo que ocurría en el Orpheum Cabaret, en esta secuencia predomina la mirada del sujeto de la enunciación que recorre toda la sala mostrando en planos generales la orquesta (fotograma 28) y la banda de Woody Herman (fotograma 29), realiza panorámicas del público sorprendido y contento con el cambio inesperado del repertorio musical y se detiene en algunos personajes del filme prestando especial atención a Nick y Miralee (fotogramas 30 y 31).

De esta forma, la película concluye con el subtexto implícito de que la instrumentalización de lo negro a manos del blanco permite que el jazz y la ópera convivan y otorga al segundo la capacidad de expresar su deseo, produciendo una variación del significado de Nueva Orleans respecto a la versión de Endie que ya no se entiende como el hogar sureño perdido por la migración sino se relaciona con un amor pasado. Nada sabemos ya de este hogar, ni de la misma Endie, que desparece a mitad de la película y solamente realiza una pequeña incursión cantando con la banda de Armstrong. Al parecer, su función ya ha terminado y los aplausos están reservados a los sujetos no racializados.

\section{Conclusiones}

El presente análisis de las construcciones estereotipadas de la imagen de Billie Holiday y de sus expresiones musicales ha intentado visibilizar los conflictos y deseos latentes en la representación de la «negritud» en el cine musical hollywoodense, concluyendo que la introducción de lo negro en el cine subvierte y refuerza las con- 


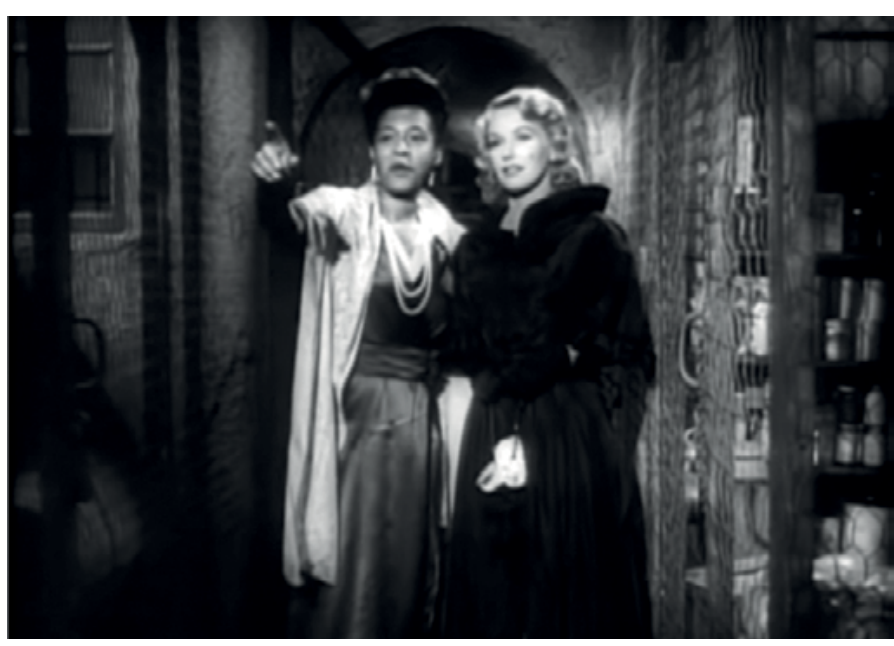

Fotograma 23

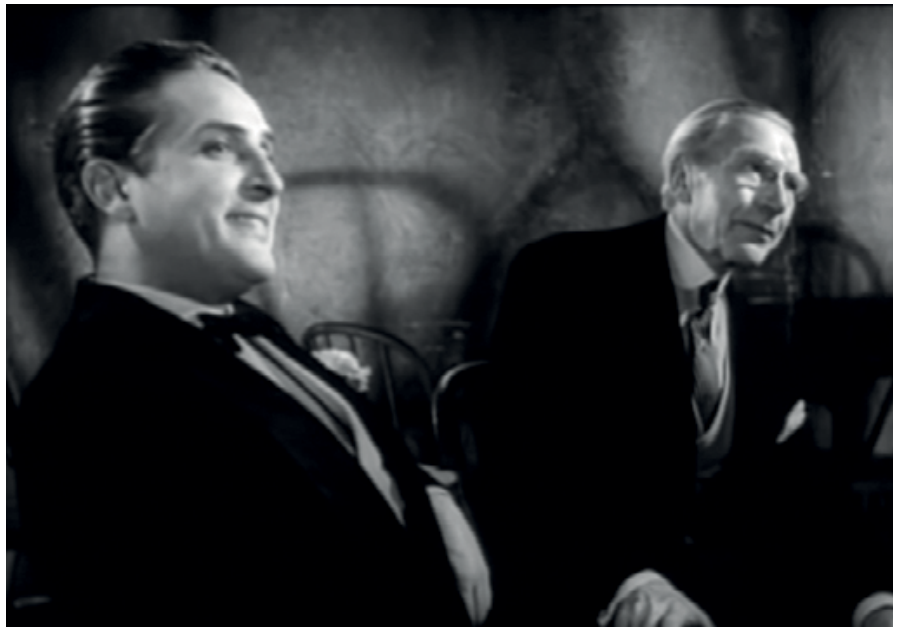

Fotograma 25

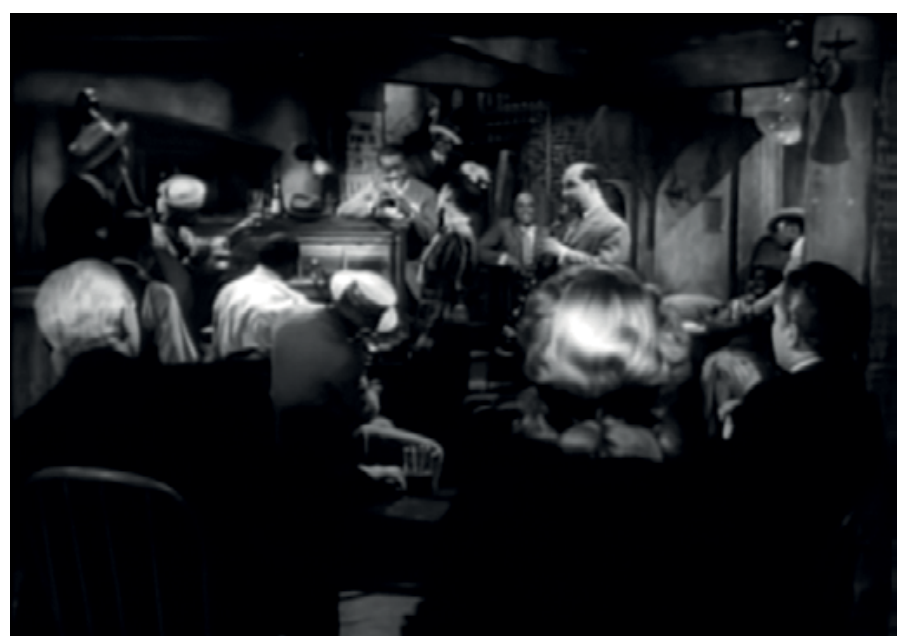

Fotograma 27

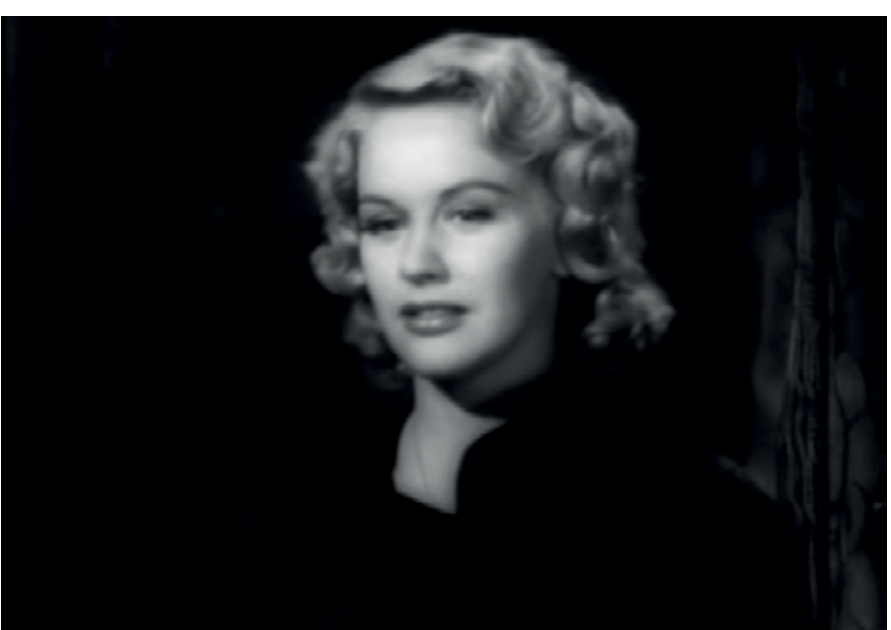

Fotograma 24

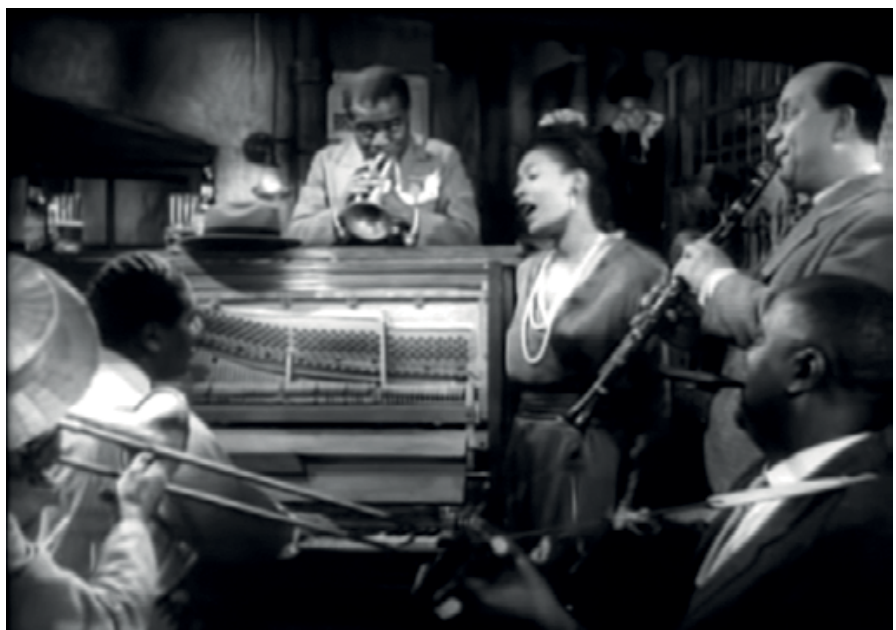

Fotograma 26

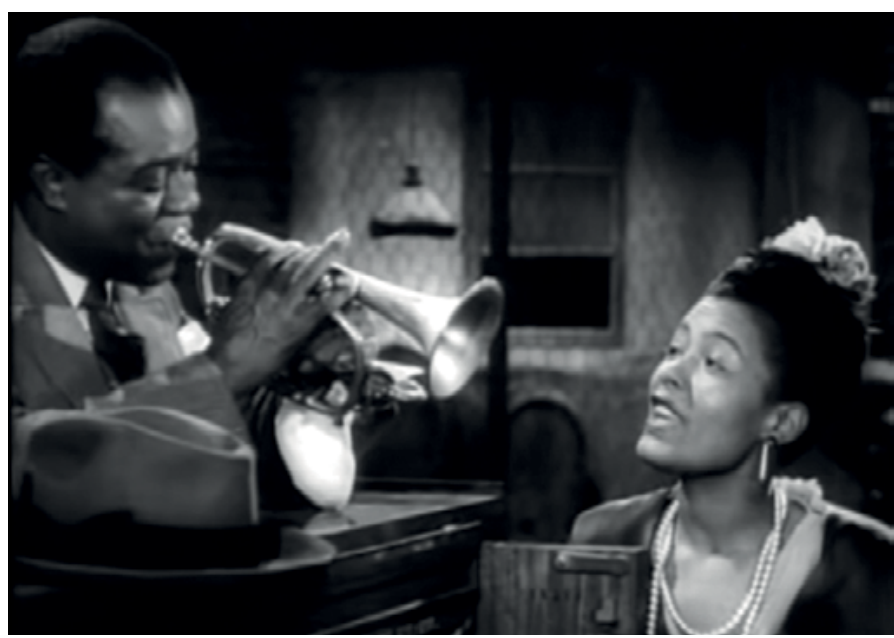

Fotograma 28 


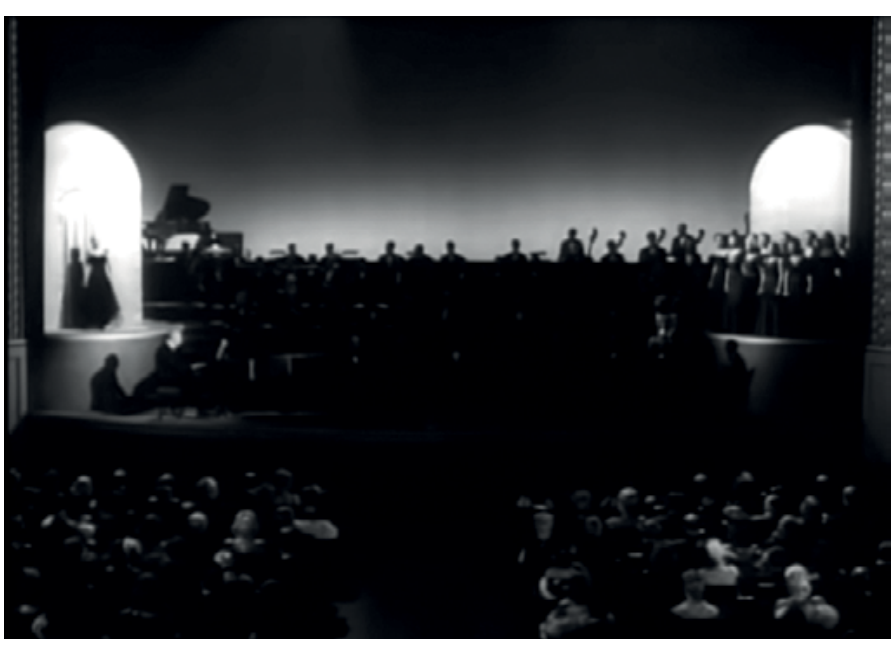

Fotograma 29

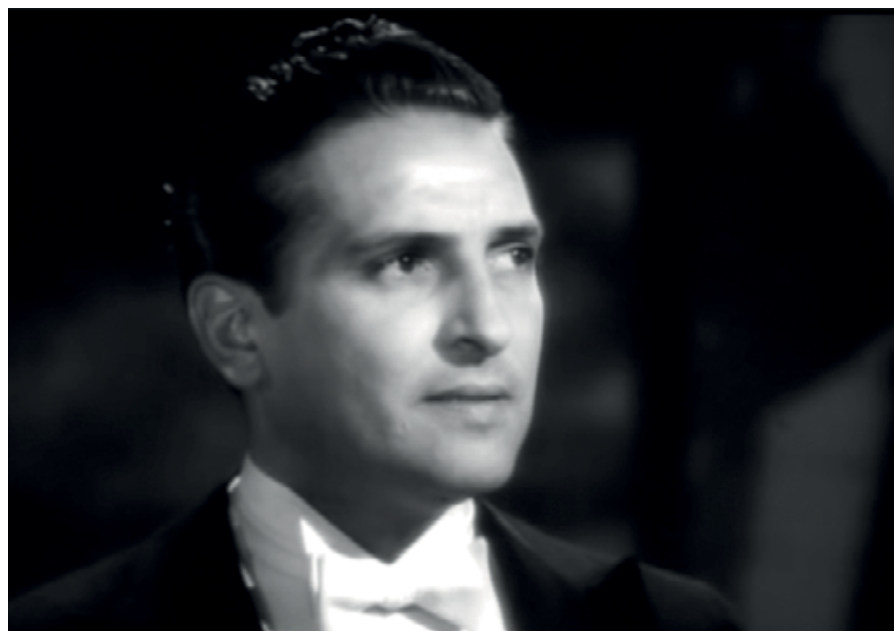

Fotograma 31

venciones ideológico-culturales adscritas al mismo. Así, la imagen de Holiday se conforma como un espacio de negociación entre el estereotipo de jezzabel y la crítica a la opresión sexista en el caso de Symphony in Black, y entre el estereotipo de criada y la crítica de la opresión racista en New Orleans.

$\mathrm{El}$ origen de esta ambivalencia se conecta con aquella empleada por el discurso hegemónico sobre la otredad, en el que el Otro se convierte en un objeto de negación y fascinación, de envidia y deseo, de exclusión e identificación. Por ello, la instrumentalización y la conformación de una imagen alrededor de la producción cultural afroa-

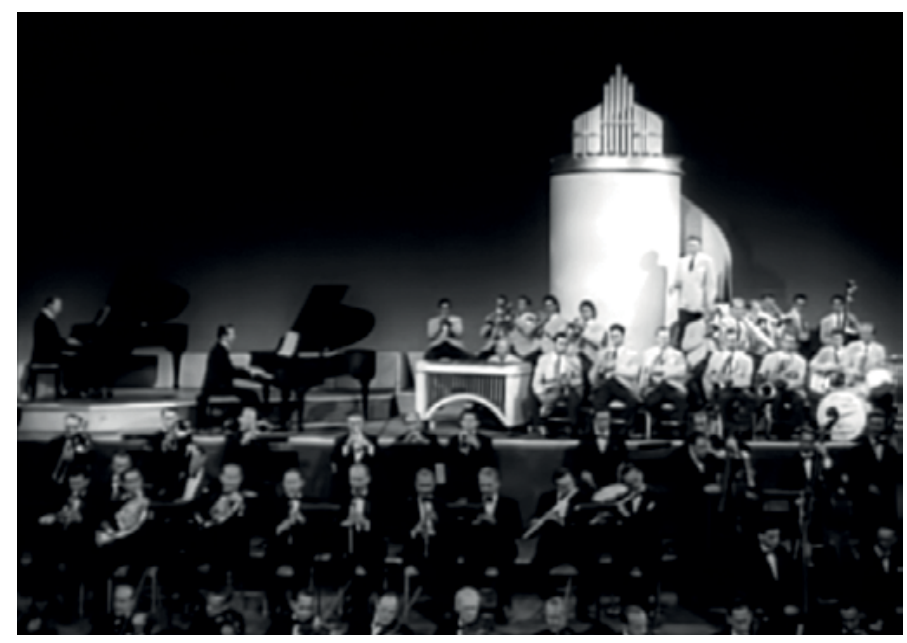

Fotograma 30

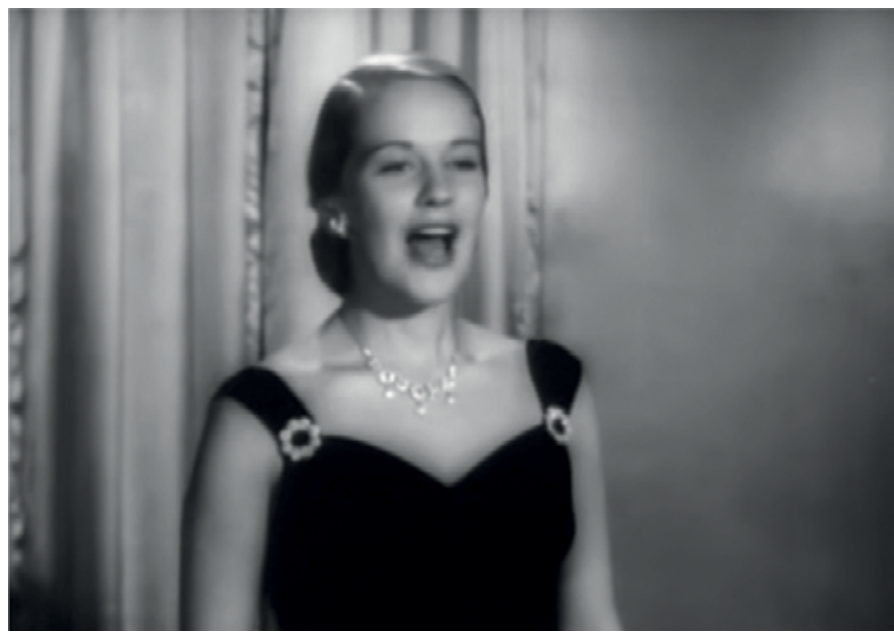

Fotograma 32

mericana parece apuntar a la elusión de los conflictos raciales, a través de la recreación de una armonía interracial jerárquica que creara una «identidad» estadounidense unificada (Rogin, 1992: 1052) en la que los afroamericanos se contentan con servir al amo blanco, y al mismo tiempo parece apuntar a la identificación con lo negro y con lo que este significa para que el imaginario blanco pueda experimentar su vitalismo, su salvajismo, su exotismo, todo aquello que hemos reprimido en el proceso de constitución de nuestro yo y que se le es atribuido (Shohat y Stam, 2002: 41) para amortiguar nuestros sentimientos de privación y carencia (Hooks, 1992: 26). 


\section{Bibliografía}

Althusser, Louis (1974), Ideología y aparatos ideológicos del Estado, Buenos Aires: Ediciones Nueva Visión.

Andújar, Olvido (2011), «Vidas en clave de jazz. Los biopics del cine norteamericano sobre el mundo de jazz», en Gloria Camarero (ed.), La biografía fílmica: Actas del Segundo Congreso Internacional de Historia y Cine, Madrid: T\&B editores, págs. 385-397.

- (2010), «Lady Sings the Blues. La construcción del personaje cinematográfico de Billie Holiday», en Carmen M. Méndez García, Ana Antón Pacheco, Isabel Durán Giménez-Rico, Joanne Neff Van Aertselaer y Ana Laura Rodríguez Redondo (eds.), Estudios de mujeres. Volumen VII. Diferencia, (des)igualdad y justicia, Madrid: Editorial Fundamentos, págs. 33-46.

Aumont, Jacques et. al (2008), «El cine y su espectadon», Estética del cine, Buenos Aires: Paidós.

BERG, Charles Merrel (1978), «Cinema Sings the Blues», Cinema Journal, vol. 17, n. ${ }^{\circ}$ 2, págs.1-12.

Blackburn, Julia (2007), Con Billie Holiday, Barcelona: Global Rhythm Press.

BRAIDOTTI, Rosi (2004), «Las figuraciones del nomadismo», Feminismo, diferencia sexual y subjetividad nómada, Barcelona: Gedisa, págs. 201-227.

Collins, Patricia Hill (2000), «Mammies, Matriarchs, and Other Controlling Images», Black Feminst Thought, Nueva York: Routledge, págs. 69-98.

Cripps, Thomas (1993), Slow Fade to Black, Nueva York: Oxford University Press.

Davis, Angela (1998), Blues Legacies and Black Feminism, Nueva York: Pantheon Books.

- (2005), Mujeres, raza y clase, Madrid: Ediciones Akal.

- (2016), Una historia de la conciencia: ensayos escogidos, Madrid: Ediciones del Oriente y del Mediterráneo.

De Lauretis, Teresa (1992), Alicia ya no: feminismo, semiótica y cine, Madrid: Cátedra.

Dyer, Richard (2002), Only Entertainment, Nueva York: Routledge.

Edwards, Brent Hayes (2002), «The Literary Ellington», Representations, vol. 77, n. ${ }^{\circ}$ 1, págs. 1-29.

Fanon, Frantz (2009), Piel negra, máscaras blancas, Madrid: Akal. Frith, Simon (2008), «Hacia una estética de la música popular», Francisco Cruces Villalobos (coord.), Las culturas musicales: lecturas de etnomusicologia, Madrid: Trotta, págs. 413-436.

Goldmark, Daniel (2005), «Jungle Jive: Race, Jazz, and Cartoons», Institute for the Study of American Music Newsletter, vol. 34 , n. ${ }^{\circ}$ 2, págs. 1-3.

Hall, Stuart (2010), Sin garantias: Trayectorias y problemáticas en estudios culturales, Popayán: Envión Editores.

- (2013), «Occidente y el Resto: discurso y poden», Ricardo Soto Sulca (ed.), Discurso y poder en Stuart Hall, Perú: Universidad Nacional del Centro del Perú, págs. 49 -112.

Holiday, Billie (2015), Lady Sings the Blues. Memorias, Barcelona: Tusquets.

Hooks, Bell (1992), Black Looks: Race and Representation, Boston: South End Press.

Howland, John (2008), «"The Blues Get Glorified”: Harlem Entertainment, Negro Nuances, and Black Symphonic Jazz», The Musical Quarterly, vol. 90, n. ${ }^{\circ}$ 3, págs. 319-370.

JabARDo, Mercedes (2008), «Desde el feminismo negro: una mirada al género y la inmigración», Liliana Suárez Navaz, Emma Martín Díaz (coords.) et al., Feminismos en la antropologia: nuevas propuestas críticas, Donostia: Ankulegi Antropologia Elkartea, págs. 39-55.

JABARDo, Mercedes (ed.) (2012), Feminismos negros, una antropología, Madrid: Traficantes de sueños.

Jones, Stacy Holman (2010), «Burnt: Writing Torch Singers and Torch Singing», Cultural Studies <=> Critical Methodologies, vol. 10, págs. 283-294.

KNAPp, Raymond (2009), «The Movie Musical», The American Musical and the Performance of Personal Identity, Princeton: Princeton University Press, págs. 65-102.

Méndez, Antonio (2016), Comunicación musical y cultura popular. Una introducción crítica, Valencia: Tirant Humanidades. ModLESKI, Tania (1995), «El cine y el continente oscuro. Raza y género en los filmes populares», Giulia Colaizzi (ed.), Feminismo y teoría fílmica, Valencia: Episteme, págs. 109-134.

Moreno Cardenal, Luisa (2007), «Pasión. Adoración. Narcisismo. La pareja de baile en tres películas», Trama y fondo, n. ${ }^{\circ} 22$, págs. $55-70$.

Mulvey, Laura (2007), «El placer visual y el cine narrativo», Karen Cordero Reuman e India Sáenz (comps.), Crítica feminista en la teoría e historia del arte, Méjico: Universidad Iberoamericana, págs. 81-95.

Lотт, Eric (2013), Love and Theft: Blackeface Minstrelsy and the American Working Class, Nueva York: Oxford University Press. 
Lugones, María (2008), «Colonialidad y género», Tabula Rasa, n. ${ }^{\circ}$ 9, págs.73-101.

- (2010), «Hacia un feminismo decolonial», Hypatia, vol. 25, n. ${ }^{\circ}$ 4, págs. $105-119$.

Rogin, Michael (1992), «Blackface, White Noise: The Jewish Jazz Singer Finds His Voice», Critical Inquiry, vol.18, n. ${ }^{\circ} 3$, págs. 417-453.

- (1994), «Democracy and Burnt Cork’: The End of Blackface, the Beginning of Civil Rights», Representations, vol. 46, págs. 1-34.

Sнонат, Ella y STAm, Robert (2002), Multiculturalismo, cine y medios de comunicación: crítica del pensamiento eurocéntrico, Barcelona: Paidós.

Sullivan, Denise (2011), Keep On Pushing: Black Power Music From Blues to Hip Hop, Chicago: Lawrence Hill Books.

Tucker, Sherrie (2004), A feminist perspective on New Orleans Jazz Women, Kansas: University of Kansas.

— (2005), «White Woman’ as Jazz Collector in the Film New Orleans (1947)», Institute for the Study of American Music Newsletter, vol. 35, n. ${ }^{\circ}$, págs. 1-2 y 13-14.
Yost, Brian (2008), «The Changing Same. The Evolution of Racial Self-Definition and Commercialization», Callaloo, vol. 31, n. ${ }^{\circ}$, págs. 1314-1334.

\section{Filmografía}

A Rhapsody in Black and Blue (Aubrey Scotto, 1932).

El cantor de jazz. (The Jazz Singer, Alan Crosland, 1927).

El nacimiento de una nación (The Birth of a Nation, David Wark Griffith, 1915).

El ocaso de una estrella (Lady Sings the Blues, Sidney J. Furie, 1972).

El rey del jazz. (King of Jaz: John Murray Anderson, 1930).

I'll Be Glad When You're Dead, You Rascal You (Dave Fleischer, 1932).

La cabaña del tío Tom (Uncle Tom's Cabin, Edwin S. Porter, 1903). New Orleans (Arthur Lubin, 1947).

St. Louis Blues (Dudley Murphy, 1929).

Stormy Weather (Andrew L. Stone, 1943).

Symphony in Black (Fred Waller, 1935).

Una cabaña en el cielo (Cabin in the Sky, Vincente Minnelli, 1943). 